Fernando Martín Alcázar, Pedro Miguel Romero Fernández, Gonzalo Sánchez Gardey ${ }^{*}$

\title{
Researching on SHRM: An Analysis of the Debate over the Role Played by Human Resources in Firm Success ${ }^{* *}$
}

Many different models have been recently proposed to explain the contribution of human resource management to organizational performance, drawing on diverse theoretical frameworks and using many different methodologies. Trying to shed light on the complex state of the art in this field of research, this paper proposes an analysis of the discipline, drawing both on a review of the literature and data obtained from an online questionnaire distributed to human resource management scholars.

Key words: Strategic Human Resource Management, Performance, Review of the Literature, State of the Art, Theories, Methodologies

* Fernando Martín Alcázar, e-mail: fernando.martin@uca.es.

Pedro Miguel Romero Fernández, e-mail: pedromigel.romero@uca.es.

Gonzalo Sánchez Gardey, e-mail: gonzalo.sanchez@uca.es.

For any commentary or suggestion on this paper, please contact: Gonzalo Sánchez Gardey, (gonzalo.sanchez@uca.es) at Facultad de Ciencias Económicas y Empresariales de Cádiz. Avenida Duque de Nájera, 8. E - 11002 Cádiz (Spain).

Authors are ordered alphabetically. This study was conducted with finance granted to the Research Group SEJ-018 (3rd Andalusian Research Plan) and the Research Project "Contribution of HRM to value creation through Social Capital Development" (Spanish Ministry of Science and Technology).

** Article received: February 27, 2004

Revised version accepted after double blind review: April 8, 2005. 


\section{Introduction}

Strategic Human Resource Management (SHRM), and its contribution to organizational success, is now consolidated as one of the most important research questions in the field of human resources. Since the traditional personnel management approach was replaced by strategic models oriented to internal aspects, academic interest shifted from administrative and bureaucratic issues to a much more integrative and proactive approach, directly related to human resource strategies and overarching philosophies (Drucker 1968; Foulkes 1975; Burack/Smith 1977; Watson 1977; Legge 1978; Rowland/Summers 1981; Russ 1982; Galosy 1983; Baird/Meshoulam 1984). Although the development of the field in these first years was criticized because of the lack of solid theoretical foundations (Zedeck/Cascio 1984; Dyer 1985; Bacharach 1989), SHRM research grew progressively, mainly after some crucial theoretical revisions such as those presented by Wright and McMahan (1992), Jackson and Schuler (1995) or the monographic issues of the International Journal of Human Resource Management (1997) and the Human Resource Management Review (1998). In this process, several SHRM models were proposed from diverse research perspectives, incorporating inputs from such very different disciplines as organization theory, sociology, organizational psychology, and management or strategic thinking (Jackson/Schuler 1995; McMahan/Virick/Wright 1999). This continuing explosion of the literature makes it necessary to undertake a systematic analysis of the different explanations that have been offered.

The objective of this paper is to review the present state of the art in the field of SHRM research, drawing on a review of the literature and on data obtained from 223 responses to an online questionnaire to Human Resource Management (HRM) scholars from different nationalities and academic contexts. Using the terminology presented by Jackson, Schuler, and Rivero (1989), Brewster $(1995,1999)$ and Delery and Doty (1996), four research perspectives have been defined to classify the literature: universalistic, contingent, configurational and contextual. These "modes of theorizing" (Delery/Doty 1996) represent four different approaches to the same research question, each emphasizing a specific dimension of the reality of SHRM. This criterion allows a systematic classification of the literature, because the definition of the four perspectives is based on the same principles, and together they show a spectrum that encompasses all possible approaches. Drawing upon data obtained from an online questionnaire distributed to scholars all over the world, this paper tries to analyse the actual landscape of SHRM research. The study focuses on the extent to which each perspective is used today, and which theoretical frameworks and research methodologies are fostering the development of a universalistic, contingent, configurational and contextual approach. The survey also included questions to determine their research objectives (Snow/Thomas 1994), and the particular areas of interest on which they have focused.

\section{The Study: sample and measures}

To develop this empirical analysis of the state of the art, an online questionnaire was distributed to HRM scholars from all over the world. It contained eight sets of items that respondents were asked to evaluate in a 0 to 5 scale, thinking about their aca- 
demic activity in the past, present and future. Each of these parts of the questionnaire was designed to extract information about certain aspects that described individuals' approach to HRM research:

1. First, academics were asked about the journals and reviews that they normally use and intend to use in the future. The 66 titles that were finally included in the list were selected from ISI's Social Citation Index. Nevertheless, a final open option was provided in case the respondent wanted to highlight any other journal.

2. In a second set of questions, scholars were asked about the Theories and Perspectives used to support their propositions. Concretely, they were asked to choose between the following options: (i) Resources and Capabilities View of the Firm, (ii) Behavioural Perspective, (iii) Open Systems Theory, (iv) Agency and Transaction Costs Theories, (v) Human Capital Theory, (vi) Social Capital Theory, (vii) Resource Dependence Theory, and (viii) Institutional Theory. This initial list was defined drawing on previous reviews of the literature (Wright/McMahan 1992; Jackson/Schuler 1995). Nevertheless, we also provided an open possibility to capture other options not included in the previous list.

3. A third set of questions was included to evaluate each respondent's research approach, drawing on the four perspectives that guide our review of the literature: Universalistic, Contingent, Configurational and Contextual perspectives (Jackson/Schuler/Rivero 1989; Brewster 1995, 1999; Delery/Doty 1996).

4. Drawing on the analysis of management research of Snow/Thomas (1994), we also tried to extract information about academics' objectives: (i) Identification of key concepts; (ii) Establishment of how and why those key concepts are related; (iii) Prediction of the future behaviour of variables; (iv) Key concepts measurement; (v) Measurement of the relationships among variables; and (vi) Test of competing theories that explain the same phenomenon.

5. Once scholars had responded about their theoretical perspective and their research objectives, they were asked to specify the methodologies that they have used, use and intend to use. Also drawing on Snow/Thomas' (1992) items academics responded about their data-gathering techniques (direct and participant observation, interviews, questionnaires, computer databases, simulations, laboratory experiments or computer simulations).

6. Regarding their data analysis methodologies, the questionnaire differentiated between qualitative (i.e. case studies, Delphi, repertory grid) and quantitative (i.e. ANOVA, regressions, cluster analysis, factorial analysis) methods.

7. After methodological issues, the questionnaire included items to identify each scholar's research interests, as Staffing, Recruitment and Selection, Compensation, Training, Socialization, Motivation or Human Resource Strategies.

8. Finally, academics were asked about their future research projects, and their interest in topics that have been highlighted as future trends in the field of HRM, such as Entrepreneurship and HRM, Diversity, Involvement or International HRM. Both in the seventh and eighth sets of items, open responses were especially important to identify present and future trends in HRM research. 
Together with all this information and in order to analyse if demographic variables could explain scholars' approaches, the questionnaire also included items about their affiliation (University or Research Centre), their nationality, and their tenure as academics (measured by the year of their first publication).

Our target population was HRM scholars, localized by the membership database of the HRM division of the Academy of Management, as well as lists of attendants from specialized Research Meetings (i.e., EIASM conferences and workshops, CRANET meetings, Cádiz University HRM Workshops, or IJHRM conferences). An email was sent to the 1656 scholars identified asking them to click a link to the questionnaire in .html format. After three rounds of emails, and once invalid responses were rejected (mainly because scholars declared they were not primarily focused in HRM), we finally received 223 responses, which represented $13.5 \%$ of the academics contacted. Surprisingly, this response rate does not differ much from those obtained normally in management surveys directed to organizations. As Table 1 shows, the majority of the sample came from Europe and the United States of America, the two main epicentres of HRM research.

Table 1: Demographic distribution of the sample.

\begin{tabular}{|l|c|c|c|c|c|}
\hline $\begin{array}{l}\text { Year of } \\
\text { scholar's first } \\
\text { academic } \\
\text { publication }\end{array}$ & Before 1980s & 1980s & 1990s & 2000s & No response \\
\cline { 2 - 6 } & $31(15.58 \%)$ & $46(23.11 \%)$ & $106(53.27 \%)$ & $13(6.53 \%)$ & $3(1.51 \%)$ \\
\hline \multirow{2}{*}{ Nationality } & European & $\begin{array}{c}\text { North } \\
\text { American }\end{array}$ & $\begin{array}{c}\text { South } \\
\text { American }\end{array}$ & $\begin{array}{c}\text { Rest of the } \\
\text { world }\end{array}$ & No response \\
\cline { 2 - 6 } & $112(50.24 \%)$ & $89(39.91 \%)$ & $4(1.79 \%)$ & $10(4.48 \%)$ & $8(3.58 \%)$ \\
\hline
\end{tabular}

To analyse the evolution of research in SHRM, we have distinguished between the universalistic, contingent, configurational and contextual perspectives (Jackson/ Schuler/Rivero 1989; Brewster 1995, 1999; Delery/Doty 1996). Scholars' responses to the third section of the questionnaire allowed us to assess their level of adoption of each of these approaches in a three-interval variable (low, medium and high level of use) that was used to ascribe academics. From $\chi^{2}$ and Kendall's Tau tests included in Table 2, we can deduce that, in general terms, these four research perspectives present theoretical and methodological differences in their analyses of the HRM-performance relationship. In fact, data show significant relationships $(p<0.05)$ between academics' perspective and their main research interests, the theories from which they develop their propositions, and their data analysis techniques. From this starting point, in the next sections, we propose a deeper analysis of the research orientation adopted by universalistic, contingent, configurational and contextual academics, completing the review of the literature with data obtained about each of these issues.

\section{Universalistic Perspective}

Universalistic propositions represent the simplest approach to the analysis of human resource strategies. Starting from the premise of the existence of certain ways of managing human resources that are always preferable, universalistic research tries to identify Best Human Resource Management Practices that, as Becker and Gerhart (1996) 
argued, must have two characteristics: (1) a demonstrated ability to improve organizational performance and (2) they must be generalizable. This objective implicitly assumes that the relationship between variables (HRM and performance or firm success) is linear, and can be extended to the entire population (Delery/Doty 1996).

Table 2: Research perspectives and topics of interest, theories and methodologies $(\mathbf{N}=223)$

\begin{tabular}{|c|c|c|c|c|c|c|c|c|c|c|c|c|c|}
\hline & \multicolumn{3}{|c|}{ Universalistic } & \multicolumn{3}{|c|}{ Contingent } & \multicolumn{3}{|c|}{ Configurational } & \multicolumn{3}{|c|}{ Contextual } \\
\hline & & \multirow{2}{*}{$\chi^{2}$ sig } & \multicolumn{2}{|c|}{ Kendall's Tau } & \multirow{2}{*}{$\chi^{2}$ sig } & \multicolumn{2}{|c|}{ Kendall's Tau } & \multirow{2}{*}{$\chi^{2} \mathrm{sig}$} & \multicolumn{2}{|c|}{ Kendall's Tau } & \multirow{2}{*}{$\chi^{2}$ sig } & \multicolumn{2}{|c|}{ Kendall's Tau } \\
\hline & & & Tau & Sig & & Tau & Sig & & Tau & Sig & & Tau & Sig \\
\hline \multirow{6}{*}{ 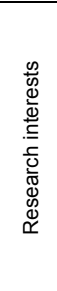 } & $\begin{array}{l}\text { Staffing, Re- } \\
\text { cruitment and } \\
\text { Selection }\end{array}$ & 0.065 & 0.089 & 0.154 & 0.051 & 0.150 & 0.013 & 0.782 & 0.034 & 0.574 & 0.009 & 0.004 & 0.944 \\
\hline & Compensation & 0.064 & 0.174 & 0.007 & 0.036 & 0.140 & 0.018 & 0.393 & 0.770 & 0.441 & 0.099 & -0.083 & 0.168 \\
\hline & Training & 0.012 & 0.154 & 0.018 & 0.046 & 0.092 & 0.123 & 0.846 & 0.005 & 0.299 & 0.039 & 0.161 & 0.008 \\
\hline & Socialization & 0.000 & 0.244 & 0.000 & 0.204 & 0.1 & 0.085 & 0.216 & 0.122 & 0.065 & 0.256 & 0.132 & 0.032 \\
\hline & Motivation & 0.134 & 0.167 & 0.006 & 0.001 & 0.226 & 0.000 & 0.248 & 0.091 & 0.139 & 0.235 & 0.137 & 0.022 \\
\hline & $\begin{array}{l}\text { Human Re- } \\
\text { source Strate- } \\
\text { gies }\end{array}$ & 0.037 & 0.128 & 0.031 & 0.047 & 0.127 & 0.034 & 0.009 & 0.196 & 0.001 & 0.001 & 0.249 & 0.000 \\
\hline \multirow{8}{*}{ 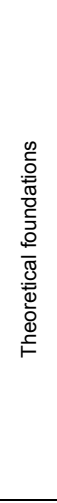 } & $\begin{array}{l}\text { Resource- } \\
\text { Based View }\end{array}$ & 0.089 & 0.127 & 0.33 & 0.020 & 0.058 & 0.340 & 0.003 & 0.226 & 0.000 & 0.069 & 0.10 & 0.868 \\
\hline & $\begin{array}{l}\text { Behavioural } \\
\text { Perspective }\end{array}$ & 0.021 & 0.109 & 0.009 & 0.018 & 0.153 & 0.001 & 0.009 & 0.075 & 0.002 & 0.000 & 0.049 & 0.031 \\
\hline & $\begin{array}{l}\text { Open Systems } \\
\text { Theory }\end{array}$ & 0.017 & 0.125 & 0.056 & 0.10 & 0.139 & 0.25 & 0.002 & 0.222 & 0.000 & 0.001 & 0.239 & 0.000 \\
\hline & $\begin{array}{l}\text { Agency and } \\
\text { Transaction } \\
\text { Costs }\end{array}$ & 0.016 & 0.169 & 0.007 & 0.46 & 0.164 & 0.005 & 0.107 & 0.167 & 0.010 & 0.041 & 0.055 & 0.358 \\
\hline & $\begin{array}{l}\text { Human Capital } \\
\text { Theory }\end{array}$ & 0.024 & 0.191 & 0.002 & 0.009 & 0.197 & 0.001 & 0.13 & 0.216 & 0.00 & 0.054 & 0.089 & 0.142 \\
\hline & $\begin{array}{l}\text { Social Capital } \\
\text { Theory }\end{array}$ & 0.218 & 0.131 & 0.041 & 0.000 & 0.176 & 0.003 & 0.001 & 0.255 & 0.000 & 0.002 & 0.149 & 0.014 \\
\hline & $\begin{array}{l}\text { Resource De- } \\
\text { pendency The- } \\
\text { ory }\end{array}$ & 0.368 & 0.107 & 0.095 & 0.005 & 0.215 & 0.000 & 0.003 & 0.234 & 0.000 & 0.002 & 0.205 & 0.001 \\
\hline & $\begin{array}{l}\text { Institutional } \\
\text { Theory }\end{array}$ & 0.132 & 0.124 & 0.054 & 0.10 & 0.205 & 0.001 & 0.002 & 0.233 & 0.000 & 0.000 & 0.310 & 0.000 \\
\hline \multirow{3}{*}{ 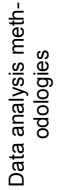 } & Qualitative & 0.015 & 0.009 & 0.083 & 0.098 & 0.110 & 0.074 & 0.009 & 0.092 & 0.045 & 0.013 & 0.204 & 0.001 \\
\hline & Univariate & 0.042 & 0.044 & 0.040 & 0.067 & 0.009 & 0.080 & 0.033 & 0.077 & 0.020 & 0.053 & -0.037 & 0.054 \\
\hline & Multivariate & 0.054 & 0.030 & 0.026 & 0.044 & 0.134 & 0.026 & 0.085 & 0.086 & 0.064 & 0.076 & -0.075 & 0.026 \\
\hline
\end{tabular}

When analysing their contribution to organizational performance, universalistic models normally choose isolated human resource practices as their level of analysis (Terpstra/Rozell 1993). In some cases, more than one Best Practice are combined, building what has been called High Performance Work Systems. Nevertheless, it must be said that, in contrast to other perspectives that are analysed below, the universalistic approach does not consider either synergic interdependence or the integration of the different practices. It just adopts an additive point of view (Pfeffer 1994; Osterman 1994; Becker/Gerhart 1996), implicitly denying the existence of different combinations of the elements that constitute the human resource system that could be equally efficient.

The value added by the universalistic perspective resides in the empirical demonstration, with high rates of significance, of the importance of the human factor and the different practices through which it is managed. While the literature has pointed 
out a great variety of best human resource practices, we can identify topics that emerge repeatedly, representing what can be considered the core of the universalistic approach. In its first years, we can observe that this perspective focused mainly on the demonstration of the importance of those practices oriented to reinforce firm's workforce, for example through variable compensation (Gerhart/Milkovich 1990), certain recruitment and selection practices (Terpstra/Rozell 1993), comprehensive training (Russell/Terborg/Powers 1985), or performance appraisal (Borman 1991). On the other hand, more recent work has considered the importance of other aspects related to workforce commitment and participation, problem resolution capabilities, teambased work, group incentives, tasks redesign or new compensation mechanisms (Youndt et al. 1996).

Compared to the other perspectives, it can be said that the universalistic approach is characterized by its lack of solid theoretical foundations, which allows it to ignore crucial relationships and constructs. Among the theoretical frameworks used by the universalists, both Agency and Transaction Costs Theories seem to have a special importance in demonstrating the superiority of certain policies that help the organization to control opportunism and reduce internal costs (Delery/Doty 1996). The Behavioural Perspective, one of the main vehicles of the contingent development, has also offered evidence to demonstrate the benefits of the adoption of practices such as shared benefits programs (Delery/Doty 1996). Finally, the basic principle of Human Capital Theory has also served to build many universalistic propositions, arguing that those organizations that use their human resource practices to develop valuable knowledge, skills and abilities present better performance levels (Duncan/Hoffman 1981; Tsang 1987; Rumberger 1987).

From a methodological point of view, the rigorous application of the deductive logic of analysis has allowed the universalistic perspective to achieve better statistical strength in hypothesis testing (Brewster 1999), developed mainly through quantitative techniques.

The universalistic point of view offers an evaluation of the contribution of the human factor to the performance of the organization. Adopting a deductive logic of analysis, these works achieve a high significance rate in the test of direct relationship between HRM and results. Considering the differences between the universalistic approaches that defend the existence of best practices and those that define best groups of practices, the contribution of this perspective can be expressed graphically as Figure 1 shows. However, this simple model has serious limitations that the literature has pointed out. In particular, it has been criticized for the narrowness of its objectives, due to the mechanical and rational character of universalistic explanations, that fail to consider crucial dimensions in the analysis of HRM strategies (Jackson et al. 1989; Delery/Doty 1996; Marchington/Grugulis 2000). Cappelli/Neumark (2001) have also pointed out important conceptual limitations to the establishment of universalistic causal relationships. The definition of its basic dependent variable (organizational performance) has been especially criticized. To measure it, universalistic authors use mainly financial indicators (Rogers/Wright 1998) that, although they are more visible and practical, ignore other effects of HRM practices, and the multiplicity of levels at which those effects take place. The organizational performance construct, core ele- 
ment of the universalistic model, must be built through a combination of measures with different origins and with different relative weight depending on the particularities of each organization. Furthermore, it is also necessary to remember that, by definition, the survival of the organization is conditioned by the confluence of the particular interests of the different stakeholders involved (Bühner 1997; Rogers/Wright 1998; Gerhart 1999; Guest 2001). More recently, authors such as Sherer/Leblevici (2001) have also criticized the stability and uniformity of the best practice approach, which does not serve to analyse the strategic change.

Figure 1: Universalistic perspective (Source: own elaboration)

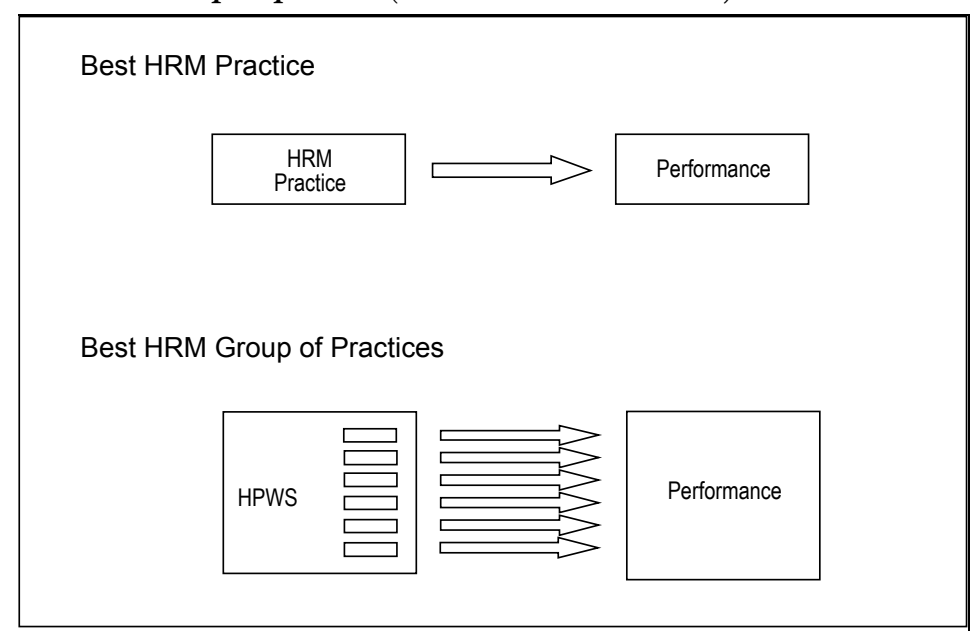

The data obtained from our questionnaire show that the universalistic perspective is no longer adopted by many scholars. The distribution of academics that have used, use and intend to use it as a research framework is limited, and shows a negative future trend (Table 3).

Table 3: Use of the universalistic perspective $(\mathrm{N}=223)$

\begin{tabular}{|l|c|c|c|}
\hline Universalistic perspective & Past use & Present use & Future use \\
\hline Low level of use & $65.5 \%$ & $66.4 \%$ & $68.7 \%$ \\
\hline Medium level of use & $21.5 \%$ & $21.1 \%$ & $19.8 \%$ \\
\hline High level of use & $13.0 \%$ & $12.5 \%$ & $12.6 \%$ \\
\hline
\end{tabular}

We consider universalists as only those authors who have used, use, or intend to use this research perspective at a high or medium level. We now analyse their research interests. Table 4 shows an increasing trend of importance that present and future universalistic models give to all of the practices. In our opinion, this could be explained by the progressive abandonment of the individual analysis of Best Practices in favour of a more inclusive High Performance Work Systems approach. It is especially interesting to observe the importance that universalistic scholars give to human resource strategies as a future research topic, which also seems to evidence a stronger emphasis on a systemic and multifunctional approach to the analysis of HRM's contribution to performance. To test whether this result was particular to the universalistic approach, 
or a common trend in the field of SHRM research, we have formally compared means between the universalistic subsample and the rest of the perspectives. ANOVA analysis shows that the parallel increment in all of the practices included in the analysis is a concrete characteristic of the universalistic perspective. Only for "Human Resource Strategies" was the F-statistic non-significant, so the increasing interest in this topic seems to reflect a general trend in HR research more than a specific characteristic of the evolution of universalistic research.

Table 4: Main areas of interest of the scholars that use the universalistic perspective

\begin{tabular}{|c|c|c|c|c|c|c|c|c|c|c|c|c|}
\hline & \multicolumn{4}{|c|}{ Past $(\mathrm{N}=77)$} & \multicolumn{4}{|c|}{ Present $(\mathrm{N}=75)$} & \multicolumn{4}{|c|}{ Future $(\mathrm{N}=70)$} \\
\hline & \multirow{2}{*}{$\%$} & \multirow{2}{*}{$M(S D)$} & \multicolumn{2}{|c|}{ ANOVA } & \multirow{2}{*}{$\%$} & \multirow{2}{*}{$M(S D)$} & \multicolumn{2}{|c|}{ ANOVA } & \multirow{2}{*}{$\%$} & \multirow{2}{*}{$M(S D)$} & \multicolumn{2}{|c|}{ ANOVA } \\
\hline & & & $\mathrm{F}$ & Sig. & & & $\mathrm{F}$ & Sig. & & & $\mathrm{F}$ & Sig. \\
\hline $\begin{array}{l}\text { Staffing, re- } \\
\text { cruitment } \\
\text { a. selection }\end{array}$ & $46.8 \%$ & $\begin{array}{c}1.81 \\
(1.940)\end{array}$ & 2.488 & 0.032 & $53.3 \%$ & $\begin{array}{c}1.87 \\
(1.826)\end{array}$ & 2.524 & 0.030 & $55.7 \%$ & $\begin{array}{c}1.89 \\
(1.798)\end{array}$ & 2.918 & 0.014 \\
\hline $\begin{array}{l}\text { Compensa- } \\
\text { tion }\end{array}$ & $57.2 \%$ & $\begin{array}{c}2.01 \\
(1.895) \\
\end{array}$ & 4.029 & 0.002 & $53.3 \%$ & $\begin{array}{c}2.01 \\
(1.983) \\
\end{array}$ & 1.906 & 0.044 & $58.6 \%$ & $\begin{array}{c}2.24 \\
(1.989) \\
\end{array}$ & 2.763 & 0.019 \\
\hline Training & $58.5 \%$ & $\begin{array}{c}1.92 \\
(1.738)\end{array}$ & 3.770 & 0.003 & $57.3 \%$ & $\begin{array}{c}2.08 \\
(1.844)\end{array}$ & 5.049 & 0.000 & $62.9 \%$ & $\begin{array}{c}2.49 \\
(1.939)\end{array}$ & 5.199 & 0.000 \\
\hline $\begin{array}{l}\text { Socializa- } \\
\text { tion }\end{array}$ & $40.3 \%$ & $\begin{array}{c}1.57 \\
(1.888)\end{array}$ & 3.479 & 0.005 & $44.0 \%$ & $\begin{array}{c}1.67 \\
(1.905)\end{array}$ & 4.414 & 0.001 & $48.6 \%$ & $\begin{array}{c}1.83 \\
(1.933)\end{array}$ & 3.537 & 0.004 \\
\hline Motivation & $58.5 \%$ & $\begin{array}{c}2.36 \\
(1.932) \\
\end{array}$ & 2.206 & 0.055 & $58.7 \%$ & $\begin{array}{c}2.44 \\
(1.926) \\
\end{array}$ & 1.903 & 0.095 & $64.3 \%$ & $\begin{array}{c}2.66 \\
(1.880) \\
\end{array}$ & 2.443 & 0.035 \\
\hline $\begin{array}{l}\text { Human } \\
\text { Resource } \\
\text { Strategies }\end{array}$ & $62.4 \%$ & $\begin{array}{c}2.35 \\
(1.925)\end{array}$ & 2.773 & 0.019 & $76.0 \%$ & $\begin{array}{c}2.92 \\
(1.836)\end{array}$ & 2.298 & 0.046 & $77.1 \%$ & $\begin{array}{c}3.19 \\
(1.852)\end{array}$ & 1.127 & 0.347 \\
\hline
\end{tabular}

Regarding its theoretical foundations, our data show that universalistic propositions have been developed mainly from a Behavioural Perspective, as well as the ResourceBased View of the Firm. In fact, these approaches, especially the first one, are used by a high percentage of universalistic scholars, which give them a relatively high importance as a basis to explain best practices and high performance work systems (Table 5). It is especially interesting to observe the growth of the use of Human Capital Theory, from which several universalistic propositions have been developed, drawing on the assumption that Skills, Knowledge and Abilities' (SKA) development practices always have a positive effect on performance. ANOVA results in this case also provide evidence that means in the use of this paradigm are significantly different from those obtained from other perspectives, so we can deduce that this trend particularly characterizes universalistic research. Contrary to what could be expected, the Agency and Transaction Costs theories do not receive the same relevance. In fact, it is interesting to observe how this perspective loses relative weight if we compare it to more recent approaches, such as Institutional or Social Capital Theories.

Our data show an interesting trend for the methodologies used by the universalistic perspective to test the HRM-performance link. As shown in Table 6, academics who adopt this approach believe that qualitative techniques will play an important role in providing evidence to explain this relationship, while tests based on quantitative and, especially, univariate tools will decline in relevance in the future. This seems to confirm the abandonment of the traditional universalistic objective of looking for direct relationships between HRM and performance, and shows a clear preference for 
more complex models including mediating and moderating variables. Universalistic works seem to be converging on the methods used by other perspectives that, as we will see below, show an increasing interest in qualitative analysis, and a clear preference for more developed quantitative methodologies.

Table 5: Theoretical frameworks used by the Universalistic Perspective

\begin{tabular}{|c|c|c|c|c|c|c|c|c|c|c|c|c|}
\hline & \multicolumn{4}{|c|}{ Past (N = 77) } & \multicolumn{4}{|c|}{ Present $(\mathrm{N}=75)$} & \multicolumn{4}{|c|}{ Future $(\mathrm{N}=70)$} \\
\hline & \multirow{2}{*}{$\%$} & \multirow{2}{*}{$M(S D)$} & \multicolumn{2}{|c|}{ ANOVA } & \multirow{2}{*}{$\%$} & \multirow{2}{*}{$M(S D)$} & \multicolumn{2}{|c|}{ ANOVA } & \multirow{2}{*}{$\%$} & \multirow{2}{*}{$M(S D)$} & \multicolumn{2}{|c|}{ ANOVA } \\
\hline & & & $\mathrm{F}$ & Sig & & & $\mathrm{F}$ & Sig. & & & $\mathrm{F}$ & Sig \\
\hline $\begin{array}{l}\text { Resource- } \\
\text { Based View }\end{array}$ & $72.7 \%$ & $\begin{array}{c}2.57 \\
(1.689) \\
\end{array}$ & 6.244 & 0.000 & $77.3 \%$ & $\begin{array}{c}2.84 \\
(1.628) \\
\end{array}$ & 2.059 & 0.072 & $72.9 \%$ & $\begin{array}{c}2.83 \\
(1.810) \\
\end{array}$ & 2.327 & 0.044 \\
\hline $\begin{array}{l}\text { Behavioural } \\
\text { Perspective }\end{array}$ & $83.1 \%$ & $\begin{array}{c}3.21 \\
(1.673) \\
\end{array}$ & 2.251 & 0.050 & $80.0 \%$ & $\begin{array}{c}3.07 \\
(1.719) \\
\end{array}$ & 0.856 & 0.312 & $85.7 \%$ & $\begin{array}{c}3.34 \\
(1.641) \\
\end{array}$ & 1.823 & 0.110 \\
\hline $\begin{array}{l}\text { Open Sys- } \\
\text { tems Theory }\end{array}$ & $58.4 \%$ & $\begin{array}{c}2.17 \\
(1.867) \\
\end{array}$ & 8.750 & 0.000 & $53.3 \%$ & $\begin{array}{c}2.08 \\
(1.908) \\
\end{array}$ & 5.449 & 0.000 & $57.1 \%$ & $\begin{array}{c}2.11 \\
(1.861) \\
\end{array}$ & 2.154 & 0.060 \\
\hline $\begin{array}{l}\text { Agency and } \\
\text { Transaction } \\
\text { Costs }\end{array}$ & $55.8 \%$ & $\begin{array}{c}1.79 \\
(1.633)\end{array}$ & 3.403 & 0.006 & $52.0 \%$ & $\begin{array}{c}1.69 \\
(1.611)\end{array}$ & 2.369 & 0.040 & $52.9 \%$ & $\begin{array}{c}1.77 \\
(1.687)\end{array}$ & 3.293 & 0.007 \\
\hline $\begin{array}{l}\text { Human Ca- } \\
\text { pital Theory }\end{array}$ & $50.6 \%$ & $\begin{array}{c}1.83 \\
(1.765) \\
\end{array}$ & 2.944 & 0.014 & $69.3 \%$ & $\begin{array}{c}2.49 \\
(1.743) \\
\end{array}$ & 3.619 & 0.004 & $74.3 \%$ & $\begin{array}{c}2.63 \\
(1.746) \\
\end{array}$ & 2.772 & 0.019 \\
\hline $\begin{array}{l}\text { Social Ca- } \\
\text { pital Theory }\end{array}$ & $39.0 \%$ & $\begin{array}{c}1.23 \\
(1.486) \\
\end{array}$ & 4.438 & 0.001 & $49.3 \%$ & $\begin{array}{c}1.71 \\
(1.707) \\
\end{array}$ & 2.417 & 0.037 & $57.1 \%$ & $\begin{array}{c}2.04 \\
(1.805) \\
\end{array}$ & 2.497 & 0.032 \\
\hline $\begin{array}{l}\text { Resource } \\
\text { Dependen- } \\
\text { cy Theory }\end{array}$ & $42.9 \%$ & $\begin{array}{c}1.42 \\
(1.533)\end{array}$ & 3.730 & 0.003 & $45.3 \%$ & $\begin{array}{c}1.57 \\
(1.595)\end{array}$ & 2.471 & 0.033 & $47.1 \%$ & $\begin{array}{c}1.66 \\
(1.641)\end{array}$ & 2.682 & 0.022 \\
\hline $\begin{array}{l}\text { Institutional } \\
\text { Theory }\end{array}$ & $42.9 \%$ & $\begin{array}{c}1.57 \\
(1.795)\end{array}$ & 2.305 & 0.046 & $50.7 \%$ & $\begin{array}{c}1.96 \\
(1.878)\end{array}$ & 3.057 & 0.011 & $54.3 \%$ & $\begin{array}{c}2.13 \\
(1.864)\end{array}$ & 2.259 & 0.050 \\
\hline
\end{tabular}

Table 6: Data analysis methodologies used by the universalistic perspective

\begin{tabular}{|c|c|c|c|c|c|c|c|c|c|c|c|c|}
\hline & \multicolumn{4}{|c|}{ Past $(\mathrm{N}=77)$} & \multicolumn{4}{|c|}{ Present $(\mathrm{N}=75)$} & \multicolumn{4}{|c|}{ Future $(\mathrm{N}=70)$} \\
\hline & \multirow{2}{*}{$\%$} & \multirow{2}{*}{$M(S D)$} & \multicolumn{2}{|c|}{ ANOVA } & \multirow{2}{*}{$\%$} & \multirow{2}{*}{$M(S D)$} & \multicolumn{2}{|c|}{ ANOVA } & \multirow{2}{*}{$\%$} & \multirow{2}{*}{$M(S D)$} & \multicolumn{2}{|c|}{ ANOVA } \\
\hline & & & $\mathrm{F}$ & Sig. & & & $\mathrm{F}$ & Sig. & & & $\mathrm{F}$ & Sig. \\
\hline $\begin{array}{l}\text { Quali- } \\
\text { tative }\end{array}$ & $55.8 \%$ & $\begin{array}{c}2.14 \\
(2.057)\end{array}$ & 1.186 & 0.317 & $57.3 \%$ & $\begin{array}{c}2.23 \\
(2.031)\end{array}$ & 0.997 & 0.433 & $63.0 \%$ & $\begin{array}{c}2.63 \\
(2.114)\end{array}$ & 0.810 & 0.544 \\
\hline $\begin{array}{l}\text { Univar } \\
\text { iate }\end{array}$ & $45.5 \%$ & $\begin{array}{c}1.5 \\
(1.831)\end{array}$ & 1.787 & 0.117 & $36.0 \%$ & $\begin{array}{c}1.19 \\
(1.641)\end{array}$ & 0.767 & 0.574 & $38.6 \%$ & $\begin{array}{c}1.20 \\
(1.575)\end{array}$ & 0.963 & 0.441 \\
\hline $\begin{array}{l}\text { Multi- } \\
\text { variate }\end{array}$ & $54.5 \%$ & $\begin{array}{c}2.14 \\
(2.088)\end{array}$ & 1.407 & 0.223 & $48.0 \%$ & $\begin{array}{c}2.20 \\
(2.224)\end{array}$ & 1.683 & 0.140 & $50.0 \%$ & $\begin{array}{c}2.36 \\
(2.284)\end{array}$ & 1.454 & 0.206 \\
\hline
\end{tabular}

\section{Contingent perspective}

This approach adds a necessary point of complexity to strategic human resource models, by including interactions that were not considered by the universalistic perspective. To do so, the models begin with a different assumption about the relationships among variables, rejecting explicitly their linearity, and proposing a model based on interactivity. The link between the dependent and the independent variables will no longer be stable. It will vary because of the incidence of other critical variables, named contingency variables. This change brings to the field of HRM Chandler's (1962) classical idea that "structure follows strategy" and the general strategic contingent model proposed by authors such as Woodward (1965), Dewar and Werbel (1979), Schoonhoven (1981), Van de Ven and Drazin (1985), or Venkatraman (1989). The application of this logic to the analysis of HRM strategies, opened by Galbraith and Nathanson (1978), offered evidence that denied the existence of a set of practices that had results 
better than others under any circumstance, showing that their influence on organizational performance will always be conditioned by other variables with which every human resource policy must be consistent.

The level of analysis adopted by followers of the contingent perspective does not differ from that of the universalists. In fact, it is also possible to identify contingent approaches from both a subfunctional and a systemic point of view. And, as happened in the previous perspective, even when several practices were analysed together, the analysis was limited to an additive point of view, without considering the mechanisms of integration of the different practices nor the synergistic effects that can appear (Delery/Doty 1996). From their analysis of contingency relationships, scholars have identified several intervening variables that can be grouped into three generic categories: strategic, organizational and environmental.

Rejecting explicitly the universal applicability of practices, contingent models argue that HRM will only have positive effects if it is consistent with an organization's strategy (Niniger 1980; Fombrun et al. 1984; Hax 1985; Van de Ven/Drazin 1985; Kerr 1985; Slocum et al. 1985; Lengnick-Hall/Lengnick-Hall 1988; Rhodes 1988 a/b; Miller 1989; Kerr/Jackofsky 1989; Butler et al. 1991; Cappelli/Singh 1992; Begin 1993). Extending this principle, some contingent articles propose that this relationship is bidirectional, considering that human resources also have an important effect on the formulation of generic strategies. The HRM strategy is no longer understood in a reactive way, but as an element that interacts with strategy. Although this argument is present in such early works as Lengnick-Hall and Lengnick-Hall (1988), it has been elaborated mainly in more recent models, such as those of Lado and Wilson (1994); Wright, McMahan, and McWilliams (1994); Richard and Johnson (2001); and Wright et al. (2001).

Aside from strategic variables, several papers have also introduced contingency relationships based on organizational variables. It has been argued that strategic HRM is conditioned by other factors such as size, technology or structure (Jones 1984; Jackson/Schuler/Rivero 1989; Jackson/Schuler 1995), as well as power relationships, (Jones 1984; Pfeffer/Cohen 1984; Pfeffer/Langton 1988; Pfeffer/Davis-Blake 1987; Balkin/Bannister 1993, Pfeffer 1987).

Finally, external determinants have also been identified as contingent variables. In this sense, it has been said that human resource strategies cannot be formulated and implemented without considering the competitive, technological, macroeconomic, and labour context of the organization (Kanter 1983, 1989; Warner 1984; Coates 1987; Walker 1988; Schuler/Walker 1990; Becker/Gerhart 1996; Boxall 1998; Jackson/ Schuler 1995).

The contingent perspective is built on a much more solid theoretical corpus than the universalistic. Contingent models draw on two theoretical frameworks: the Behavioural Perspective and the Resource-Based View of the Firm. From the first, a wide set of propositions concerning the HR-strategy fit have been developed (Miles/Snow 1984; Schuler 1987; Schuler/Jackson 1987 a/b). The Behavioural Perspective has also served to study the incidence of other organizational and external variables, such as those introduced by Jackson/Schuler (1995). The Resource Based View has mainly focused on the strategic fit, pointing out that it is necessary to consider a reciprocal link between the human factor and corporative strategic decisions. As this organiza- 
tional asset is characterized by its high value, rareness and inimitability, it must be considered a key resource of the strategic configuration of the firm (Wright/McMahan 1992; Barney/Wright 1998; Boxall 1998; Hitt et al. 2001; Richard/Johnson 2001; Wright et al. 2001; De Sáa Pérez/García Falcón 2002). Together with the Behavioural and the Resources and Capabilities perspectives, we can point out contingent evidence that comes from Institutional Theory (Eisenhardt 1988), from Transaction Costs Jones 1984; Gómez Mejía/Tosi/Hinkin 1987; Tosi/Gómez Mejía 1989, 1994; Gómez Mejía/Balkin 1991; Romero/Valle 2001), from Social Capital Theory (UhlBien et al. 2000), and from Resource Dependence Theory, that proposes the introduction of power relationships as contingency variables (Pfeffer/Cohen 1984; Pfeffer/ Davis-Blake 1987; Pfeffer/Langton 1988; Balkin/Bannister 1993).

As in the universalistic perspective, contingent empirical analysis is guided by a deductive logic of analysis and a quantitative focus. Although, in this case, we find that the statistical techniques used are much more varied, the level of significance achieved in their empirical tests is not as high as in the universalistic case, perhaps due to the complexity of the relationships included in contingent models. Reviewing the tools used by these works we can observe that regression techniques have been commonly applied (Koch/McGrath 1996; Youndt et al. 1996; Huselid, Jackson/Schuler 1997; Godard 1997; Keng-Howe Chew/Chong 1999; Khatri 2000; Way Kwong et al. 2001), although many contingent hypotheses have also been tested by other statistical tools such as factorial analysis (Ackerman 1986), cluster analysis (Romero/Valle 2001; De Sáa Pérez/García Falcón 2002) or meta-analytical techniques (Tubre/Collins 2001). As significant exceptions we also observe some articles that investigate the influence of contingent variables through qualitative methods, based mainly on case studies (Boxall/Steeneveld 1999; Shafer et al. 2001; Kelliher/Perret 2001).

In light of our argument, we see that the universalist perspective is enhanced by the contingent proposal, given that the worth of any specific human resource decision will always depend on its fit to the strategic, organizational and external context of the organization. The added complexity introduced by those models is summarized graphically in Figure 2. While the contingent contribution to theory building in the field of SHRM has been crucial, it has some limitations. Becker and Gerhart (1996), for example, argue that the methodology applied by the contingent perspective to test their hypotheses leads them to universalistic conclusions. The reason is the extensive use of regression techniques, from which they deduce that the effect of a change on an HRM variable, measured by the organizational performance, will be always the same, and could be considered as universal, under a certain level of the contingency variable (Becker/Gerhart 1996; Sherer/Leblevici 2001). Other authors, such as Boudreau and Ramstad (1999) or Wright and Sherman (1999), believe that contingent research needs to improve its HRM measures. The problem appears when the contingency variable analysed is corporate strategy. In these cases, the contingent models usually apply generic typologies, such as that of Miles and Snow (1978). Following Chadwick and Cappelli (1999), it can be said that it is necessary to define typologies designed specifically for HRM research, able to encompass all the complexity of this research project. Furthermore, the contingent perspective has also been criticized because of its micro orientation, and because of its misunderstanding of the strategic 
definition process. In this sense, we can observe the disagreement of a broad stream of the literature with a main contingent prescription: the superior performance of those organizations that follow the HRM-strategy fit. Many authors, as Becker and Gerhart (1996), believe that the design of fitted management systems leads to a too rigid and inflexible structure that does not respond to the need for adaptability in today's economic environment.

Figure 2: Contingent approach (Source: own elaboration)

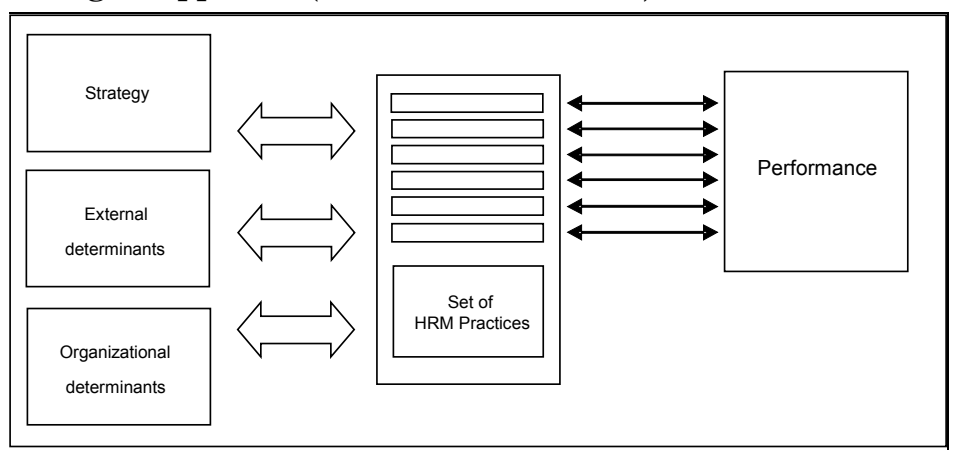

Drawing on our data, we can deduce that, today, the contingent perspective is much more popular than the universalistic one (Table 7). The more complete model of the former seems to have displaced the simple universalistic framework, which fails to consider the many variables and relationships necessary to explain human resource strategies. We can also conclude from Table 7 that the contingent model will be of increasing importance in the future. In fact, for the category 'High level of use', we observe considerable growth of this perspective as a research option for future work.

Table 7: Use of the contingent perspective $(\mathrm{N}=223)$

\begin{tabular}{|l|c|c|c|}
\hline Contingent perspective & Past use & Present use & Future use \\
\hline Low level of use & $32.7 \%$ & $26.9 \%$ & $28.2 \%$ \\
\hline Medium level of use & $29.2 \%$ & $32.7 \%$ & $25.1 \%$ \\
\hline High level of use & $38.1 \%$ & $40.3 \%$ & $46.6 \%$ \\
\hline
\end{tabular}

Following the same schema used to describe the universalistic approach, we started our analysis of the data obtained from scholars that were classified under the contingent perspective describing their research interests. From the data included in Table 8, we can observe that they also reflect the general trend of increasing interest in HR strategies, which receive the highest valuation in the three periods considered. Furthermore, our data also show an intense level of adoption of the rest of the topics listed. This supports our theoretical conclusion that the contingent perspective has been (and will be) applied to analyse the human resource function from both: (1) a subfunctional level - describing how certain policies, when linked to organizational strategy, have a positive effect on performance; and (2) a holistic point of view analysing the fit between a firm's strategic orientation and the set of practices that are under the umbrella of human resource strategy (Wright/McMahan 1992). 
Table 8: Main areas of interest of contingent scholars

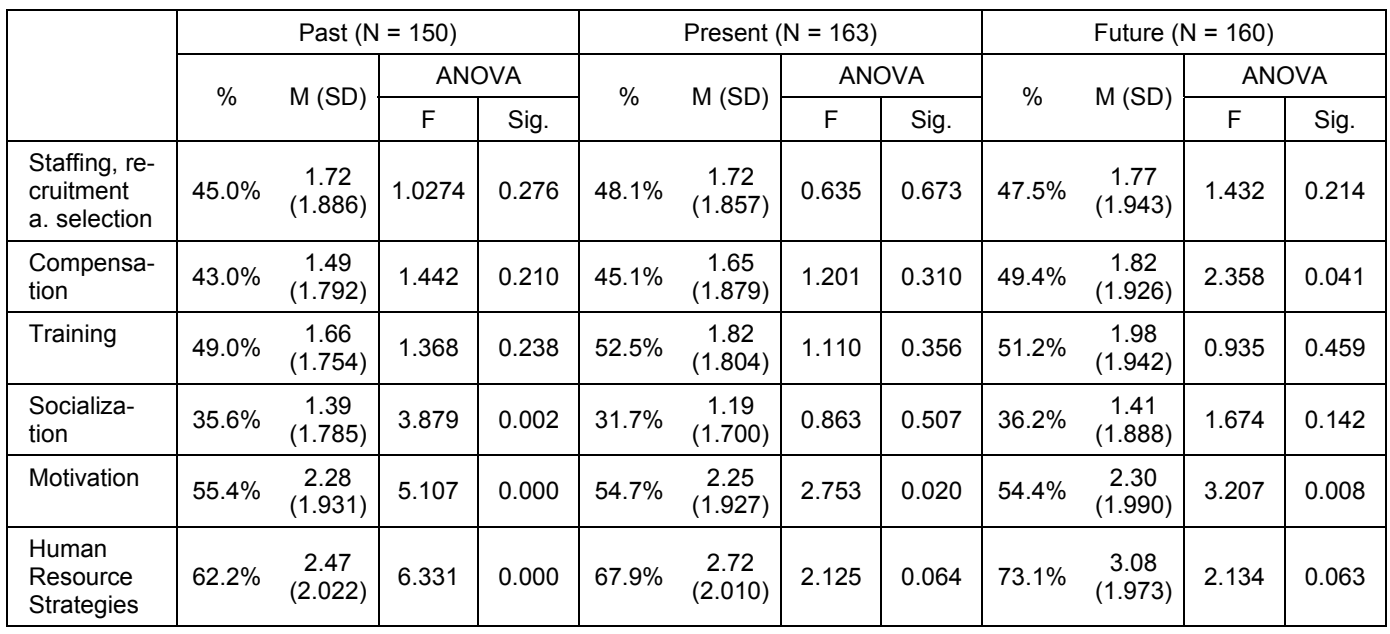

Regarding its theoretical foundations, Table 9 confirms that contingent models have been proposed mainly by scholars using the Behavioural theory and the ResourceBased View of the Firm, as we see both from the percentage of respondents and the average valuation that they receive. Together with these approaches, that build the core, not only of the contingent perspective but of the whole discipline, our data also shows a particular increasing trend in the use of more recent paradigms such as the Institutional and Social Capital.

Table 9: Theoretical foundations of the contingent perspective

\begin{tabular}{|c|c|c|c|c|c|c|c|c|c|c|c|c|}
\hline & \multicolumn{4}{|c|}{ Past $(N=150)$} & \multicolumn{4}{|c|}{ Present $(\mathrm{N}=163)$} & \multicolumn{4}{|c|}{ Future $(N=160)$} \\
\hline & \multirow{2}{*}{$\%$} & \multirow{2}{*}{$M(S D)$} & \multicolumn{2}{|c|}{ ANOVA } & \multirow{2}{*}{$\%$} & \multirow{2}{*}{$M(S D)$} & \multicolumn{2}{|c|}{ ANOVA } & \multirow{2}{*}{$\%$} & \multirow{2}{*}{$M(S D)$} & \multicolumn{2}{|c|}{ ANOVA } \\
\hline & & & $\mathrm{F}$ & Sig. & & & $\mathrm{F}$ & Sig. & & & $F$ & Sig. \\
\hline $\begin{array}{l}\text { Resource- } \\
\text { Based View }\end{array}$ & $61.3 \%$ & $\begin{array}{c}2.25 \\
(1.796)\end{array}$ & 2.269 & 0.049 & $70.6 \%$ & $\begin{array}{c}2.58 \\
(1.735)\end{array}$ & 1.482 & 0.197 & $71.9 \%$ & $\begin{array}{c}2.69 \\
(1.799)\end{array}$ & 2.862 & 0.016 \\
\hline $\begin{array}{l}\text { Behavioural } \\
\text { Perspective }\end{array}$ & $79.3 \%$ & $\begin{array}{c}3.16 \\
(1.750)\end{array}$ & 7.202 & 0.000 & $80.4 \%$ & $\begin{array}{c}3.01 \\
(1.685)\end{array}$ & 3.100 & 0.010 & $80.0 \%$ & $\begin{array}{c}2.99 \\
(1.734)\end{array}$ & 3.045 & 0.011 \\
\hline $\begin{array}{l}\text { Open Sys- } \\
\text { tems Theory }\end{array}$ & $56.7 \%$ & $\begin{array}{c}2.05 \\
(1.837)\end{array}$ & 3.807 & 0.003 & $50.9 \%$ & $\begin{array}{c}1.90 \\
(1.776)\end{array}$ & 2.030 & 0.076 & $50.6 \%$ & $\begin{array}{c}1.84 \\
(1.791)\end{array}$ & 0.480 & 0.791 \\
\hline $\begin{array}{l}\text { Agency and } \\
\text { Transaction } \\
\text { Costs }\end{array}$ & $42.7 \%$ & $\begin{array}{c}1.53 \\
(1.713)\end{array}$ & 3.292 & 0.007 & $39.3 \%$ & $\begin{array}{c}1.38 \\
(1.641)\end{array}$ & 1.268 & 0.279 & $41.2 \%$ & $\begin{array}{c}1.46 \\
(1.704)\end{array}$ & 1.495 & 0.193 \\
\hline $\begin{array}{l}\text { Human Ca- } \\
\text { pital Theory }\end{array}$ & $49.3 \%$ & $\begin{array}{c}1.79 \\
(1.759)\end{array}$ & 3.700 & 0.003 & $60.1 \%$ & $\begin{array}{c}2.15 \\
(1.751)\end{array}$ & 1.858 & 0.103 & $60.0 \%$ & $\begin{array}{c}2.25 \\
(1.893)\end{array}$ & 0.792 & 0.556 \\
\hline $\begin{array}{l}\text { Social Ca- } \\
\text { pital Theory }\end{array}$ & $36.7 \%$ & $\begin{array}{c}1.23 \\
(1.525)\end{array}$ & 5.227 & 0.000 & $44.2 \%$ & $\begin{array}{c}1.48 \\
(1.679)\end{array}$ & 2.662 & 0.023 & $46.2 \%$ & $\begin{array}{c}1.67 \\
(1.807)\end{array}$ & 1.425 & 0.216 \\
\hline $\begin{array}{l}\text { Resource } \\
\text { Dependency } \\
\text { Theory }\end{array}$ & $45.3 \%$ & $\begin{array}{c}1.44 \\
(1.574)\end{array}$ & 6.293 & 0.000 & $42.3 \%$ & $\begin{array}{c}1.45 \\
(1.618)\end{array}$ & 2.969 & 0.013 & $43.7 \%$ & $\begin{array}{c}1.51 \\
(1.656)\end{array}$ & 3.224 & 0.008 \\
\hline $\begin{array}{l}\text { Institutional } \\
\text { Theory }\end{array}$ & $44.7 \%$ & $\begin{array}{c}1.57 \\
(1.739)\end{array}$ & 5.184 & 0.000 & $46.6 \%$ & $\begin{array}{c}1.73 \\
(1.823)\end{array}$ & 1.908 & 0.094 & $48.7 \%$ & $\begin{array}{c}1.84 \\
(1.848)\end{array}$ & 1.303 & 0.264 \\
\hline
\end{tabular}


Table 10 shows the empirical methodologies used for hypothesis testing under the contingent perspective. Again, in this case, our data reflect the general trend, as ANOVA results also confirm. We can observe that multivariate quantitative techniques are used much more than univariate ones. From this, it is possible to deduce that the structure of contingent models requires sophisticated statistical tools, designed to analyse the more complex relationships among variables. Furthermore, results for the present and future show a significant growth of the use of qualitative techniques, perhaps due to the generalization of case study research.

Table 10: Data analysis methodologies used by the contingent perspective

\begin{tabular}{|c|c|c|c|c|c|c|c|c|c|c|c|c|}
\hline & \multicolumn{4}{|c|}{ Past $(\mathrm{N}=150)$} & \multicolumn{4}{|c|}{ Present $(\mathrm{N}=163)$} & \multicolumn{4}{|c|}{ Future $(\mathrm{N}=160)$} \\
\hline & \multirow{2}{*}{$\%$} & \multirow{2}{*}{$M(S D)$} & \multicolumn{2}{|c|}{ ANOVA } & \multirow{2}{*}{$\%$} & \multirow{2}{*}{$M(S D)$} & \multicolumn{2}{|c|}{ ANOVA } & \multirow{2}{*}{$\%$} & \multirow{2}{*}{$M(S D)$} & \multicolumn{2}{|c|}{ ANOVA } \\
\hline & & & $\mathrm{F}$ & Sig. & & & $\mathrm{F}$ & Sig. & & & $\mathrm{F}$ & Sig. \\
\hline $\begin{array}{l}\text { Qua- } \\
\text { litati- } \\
\text { ve }\end{array}$ & $36.7 \%$ & $\begin{array}{c}2.35 \\
(2.043)\end{array}$ & 3.375 & 0.006 & $47.9 \%$ & $\begin{array}{c}2.40 \\
(1.966)\end{array}$ & 1.697 & 0.137 & $55.0 \%$ & $\begin{array}{c}2.65 \\
(2.016)\end{array}$ & 1.992 & 0.081 \\
\hline $\begin{array}{l}\text { Uni- } \\
\text { varia- } \\
\text { te }\end{array}$ & $35.3 \%$ & $\begin{array}{c}1.29 \\
(1.786)\end{array}$ & 1.058 & 0.385 & $36.2 \%$ & $\begin{array}{c}1.25 \\
(1.685)\end{array}$ & 0.609 & 0.693 & $33.7 \%$ & $\begin{array}{c}1.13 \\
(1.605)\end{array}$ & 1.410 & 0.222 \\
\hline $\begin{array}{l}\text { Multi } \\
\text { va- } \\
\text { riate }\end{array}$ & $50.7 \%$ & $\begin{array}{c}2.06 \\
(2.153)\end{array}$ & 1.694 & 0.137 & $54.6 \%$ & $\begin{array}{c}2.28 \\
(2.164)\end{array}$ & 2.860 & 0.016 & $53.1 \%$ & $\begin{array}{c}2.33 \\
(2.234)\end{array}$ & 3.798 & 0.003 \\
\hline
\end{tabular}

\section{Configurational perspective}

The configurational perspective offers an analysis of the synergic integration of the different variables that constitute this organizational function. To do so, it always adopts a systemic point of view that allows a deep study of the "black box" considered by the universalistic and contingent models. The HRM system is defined here as a multidimensional set of different elements that can be combined to form an infinite number of possible configurations. From amongst these, the configurational perspective extracts management patterns that represent different organizational possibilities (Miller/Friesen 1984; Ketchen/Thomas/Snow 1993). These ideal management models must be characterized by: (1) their consistency with external, organizational and strategic conditions, as the contingent model explained, and (2) they must be also internally consistent (Venkatraman/Prescott 1990; Doty et al. 1993; Delery/Doty 1996). It is important to notice that configurational patterns, more than empirically observable phenomena, are ideal types, similar to those proposed by sociological theory (Weber 1949). As Meyer et al. (1993) and Doty and Glick (1994) argued, real organizations will tend to resemble one of these models, although they will not exactly fit any one of them.

Underlying this new point of view, we find an important change in the way of understanding the relationship among the variables involved in HRM strategies. The linearity is broken with the introduction of the concept of synergy. The interdependence of the practices means that certain combinations could multiply or divide the effect of the whole system. That makes the universalistic High Performance Work Systems gain a necessary point of complexity. Configurational models do not forget the relevance of contingent relationships, and adopt explicitly the principle of equifinality. Under this premise, they suppose that the same business objectives can be reached 
through different systems of practices that can be equally efficient (Delery/Doty 1996). In this point, they forget the universalistic purpose of finding Best Human Resource Practices.

The explanation of the internal dynamics of the HRM system was only possible through the application of General Systems Theory, which allowed a deep understanding of human resource strategies as a complex phenomenon, constituted by different elements that interact in a dynamic and synergistic way (Wright/Snell 1991; Snell 1992; Snell/Dean 1992). But the configurational approach has also received ideas from other paradigms, such as the Resource-Based View of the Firm (Lepak/Snell 1998; Wright/Snell 1998; Delery 1998; Delery/Shaw 2001), Behavioural Theory (Miles/Snow 1984), Transaction Costs Theory (Lepak/Snell 1998/1999), and Human Capital Theory (Lepak/Snell 1999). All those frameworks were summarized in the comprehensive model of Human Resource Architecture, proposed by Lepak/Snell (1998, 1999), that supposes a more sophisticated insight into the internal dynamic of the HRM function.

To develop its internal analysis, the configurational perspective has mainly used statistical techniques that allow the extraction of management patterns, such as cluster (Arthur 1994; MacDuffie 1995), factorial (Ackerman 1986; MacDuffie 1995), or neural network analysis (Woelfel 1993). From a different point of view, we can also find examples of regressions, as those developed by Wood and Albanese (1995). As with the contingent perspective, some aspects of configurational methodologies need to be refined. The study of the combination of the different elements that constitute the function and its synergistic relationships requires more sophisticated techniques, able to analyse the complexity of this internal integration (Delery 1998).

Universalistic and contingent approaches study the influence of HRM strategies in corporate performance without considering internal interactions. This is where the configurational contribution lies. It completes the model by defining the elements that constitute the system and by systematically and exhaustively analysing their integration mechanisms. This allows us to define ideal management models that can be equally efficient. Each organization must decide between them, considering its particular internal and external conditions (Figure 3). It is important to remember that the patterns proposed by the configurational models are just ideal types (Delery/Doty 1996). This fact implies simplification of the reality. We find another limitation of the configurational approach in its empirical development. The complex internal interactions are quite difficult to measure with the techniques that are commonly used in the field of organizational and strategic research. Because of this, the empirical evidence for configurational conclusions is much poorer than, for example, the universalistic (Delery 1998).

Although the use of configurational perspective is growing, the percentage of scholars that have used and intend to use it seems to be falling by comparison with the contingent approach (Table 11). These data could be explained by the fact that the configurational perspective focuses on a concrete dimension of human resource strategies (integration of practices), so we cannot deduce from them that the analysis of HRM configurations is losing relative weight. Human resource strategies are also the main area of interest, not only in the future, but also for the past and present (Tabvle 12), but in this case, means for this topic of analysis are even significantly 
higher, as ANOVA shows. Again, this fact can be explained by the main purpose of configurational analysis, which focuses mainly on global and systemic issues, not considering the different human resource practices separately.

Figure 3: Configurational Perspective (Source: own elaboration)

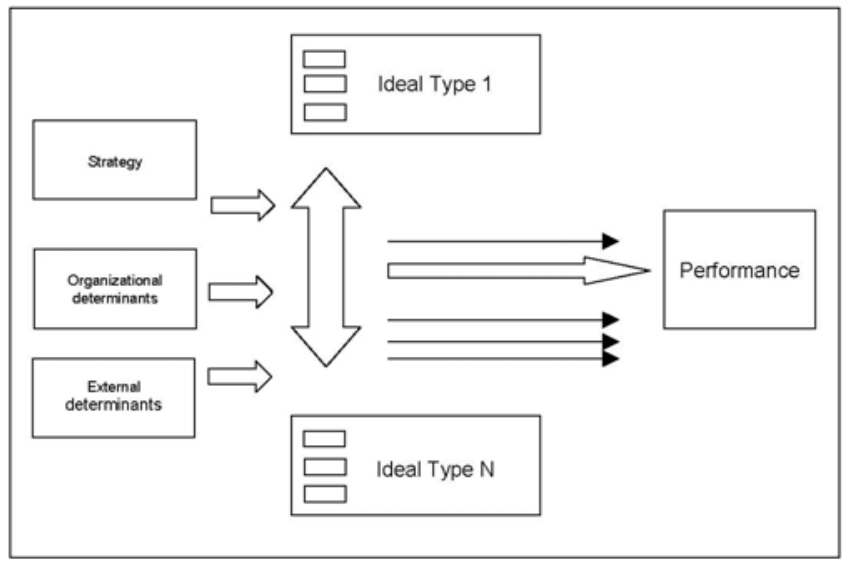

Table 11: Use of the configurational perspective $(\mathrm{N}=223)$

\begin{tabular}{|l|c|c|c|}
\hline Configurational perspective & Past use & Present use & Future use \\
\hline Low level of use & $67.7 \%$ & $63.6 \%$ & $58.7 \%$ \\
\hline Medium level of use & $20.2 \%$ & $17.9 \%$ & $20.2 \%$ \\
\hline High level of use & $12.1 \%$ & $18.4 \%$ & $21.1 \%$ \\
\hline
\end{tabular}

Table 12: Main areas of interest of configurational scholars

\begin{tabular}{|c|c|c|c|c|c|c|c|c|c|c|c|c|}
\hline & \multicolumn{4}{|c|}{ Past $(\mathrm{N}=72)$} & \multicolumn{4}{|c|}{ Present $(\mathrm{N}=81)$} & \multicolumn{4}{|c|}{ Future $(\mathrm{N}=92)$} \\
\hline & \multirow{2}{*}{$\%$} & \multirow{2}{*}{$M(S D)$} & \multicolumn{2}{|c|}{ ANOVA } & \multirow{2}{*}{$\%$} & \multirow{2}{*}{$M(S D)$} & \multicolumn{2}{|c|}{ ANOVA } & \multirow{2}{*}{$\%$} & \multirow{2}{*}{$M(S D)$} & \multicolumn{2}{|c|}{ ANOVA } \\
\hline & & & $\mathrm{F}$ & Sig. & & & $\mathrm{F}$ & Sig. & & & $\mathrm{F}$ & Sig. \\
\hline $\begin{array}{l}\text { Staffing, } \\
\text { recruit- } \\
\text { ment and } \\
\text { selection }\end{array}$ & $45.1 \%$ & $\begin{array}{c}1.73 \\
(1.804)\end{array}$ & 0.756 & 0.528 & $48.7 \%$ & $\begin{array}{c}1.74 \\
(1.812)\end{array}$ & 0.952 & 0.448 & $50.0 \%$ & $\begin{array}{c}1.82 \\
(1.910)\end{array}$ & 1.354 & 0.243 \\
\hline $\begin{array}{l}\text { Compen- } \\
\text { sation }\end{array}$ & $47.9 \%$ & $\begin{array}{c}1.73 \\
(1.920) \\
\end{array}$ & 2.129 & 0.063 & $40.0 \%$ & $\begin{array}{c}1.54 \\
(1.902) \\
\end{array}$ & 2.533 & 0.030 & $53.3 \%$ & $\begin{array}{c}1.90 \\
(1.922) \\
\end{array}$ & 2.706 & 0.021 \\
\hline Training & $50.7 \%$ & $\begin{array}{c}1.72 \\
(1.845)\end{array}$ & 0.818 & 0.523 & $47.3 \%$ & $\begin{array}{c}1.78 \\
(1.800)\end{array}$ & 1.086 & 0.369 & $51.1 \%$ & $\begin{array}{c}1.96 \\
(1.966)\end{array}$ & 1.292 & 0.268 \\
\hline $\begin{array}{l}\text { Socializa- } \\
\text { tion }\end{array}$ & $43.7 \%$ & $\begin{array}{c}1.61 \\
(1.785) \\
\end{array}$ & 5.795 & 0.000 & $38.0 \%$ & $\begin{array}{c}1.38 \\
(1.712) \\
\end{array}$ & 2.601 & 0.026 & $38.0 \%$ & $\begin{array}{c}1.35 \\
(1.738) \\
\end{array}$ & 0.600 & 0.700 \\
\hline Motivation & $51.4 \%$ & $\begin{array}{c}2.34 \\
(1.977) \\
\end{array}$ & 2.752 & 0.020 & $54.4 \%$ & $\begin{array}{c}2.29 \\
(1.855) \\
\end{array}$ & 2.043 & 0.074 & $51.1 \%$ & $\begin{array}{c}2.09 \\
(1.920) \\
\end{array}$ & 0.497 & 0.778 \\
\hline $\begin{array}{l}\text { Human } \\
\text { Resource } \\
\text { Strategies }\end{array}$ & $70.0 \%$ & $\begin{array}{c}2.84 \\
(1.968)\end{array}$ & 5.377 & 0.000 & $75.0 \%$ & $\begin{array}{c}2.93 \\
(1.847)\end{array}$ & 2.322 & 0.044 & $80.4 \%$ & $\begin{array}{c}3.38 \\
(1.766)\end{array}$ & 4.043 & 0.002 \\
\hline
\end{tabular}

Regarding its theoretical foundations, the configurational perspective follows what seems to be a common trend in HRM research (Table 13). Again the Behavioural Perspective and the Resource-Based View are the most used frameworks, and, as for the universalistic perspective, Human Capital Theory has been prominent. Compared with 
the other perspectives it is also possible to observe that in the origins of the configurational perspective, Open Systems Theory played an important role, significantly more so than the other approaches. Our data seem to confirm that this generic framework has offered many of the elements that configurational models used to build their internal explanation of human resource strategies.

Table 13: Theoretical foundations of the configurational perspective

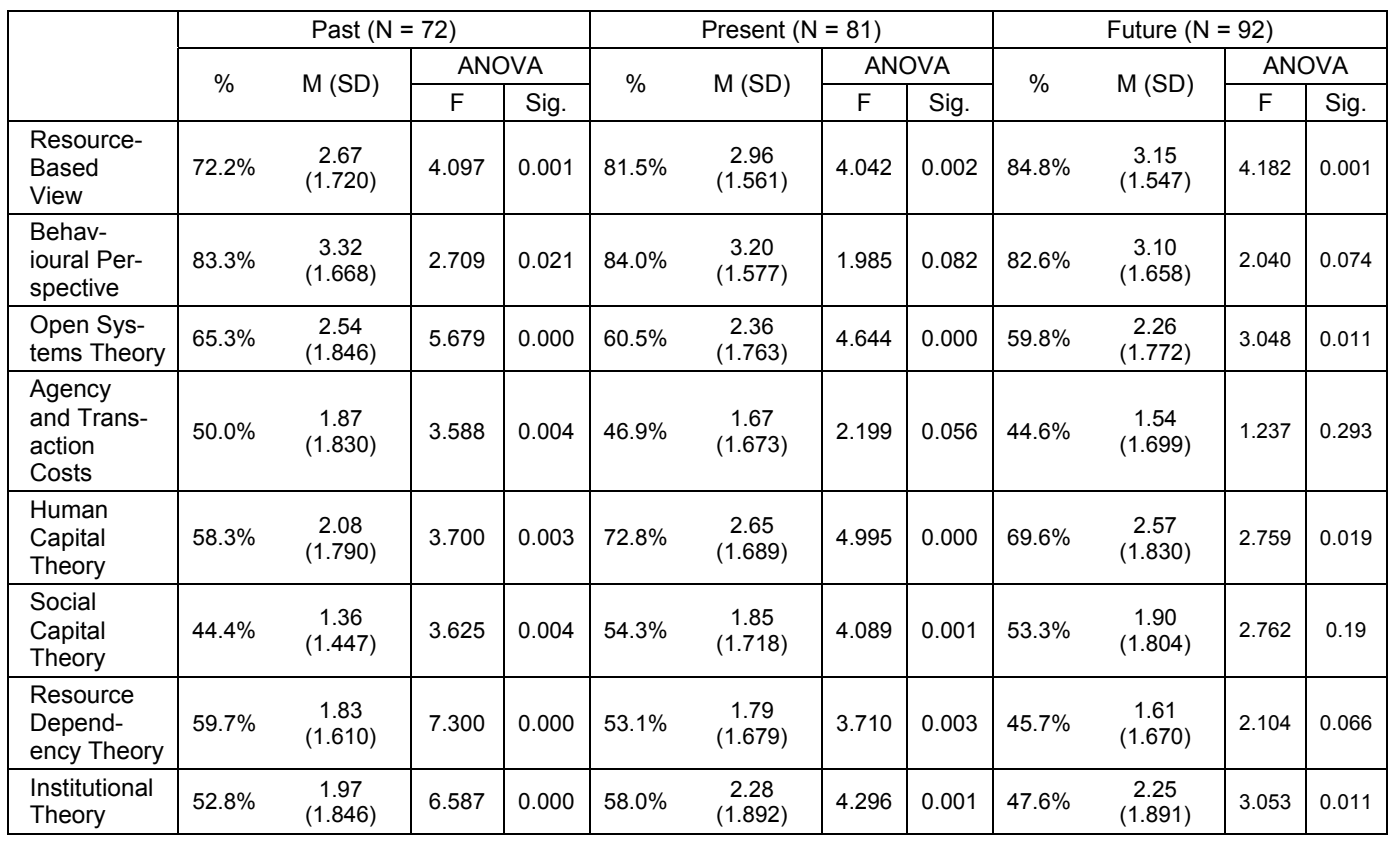

Table 14 summarizes the responses of configurational scholars when they were asked about the methodologies that they use to test their propositions. The results seem to be similar to those obtained from other perspectives, although a deeper analysis of the data shows an even stronger emphasis on the use of multivariate techniques, such as cluster or factorial methods, that help scholars analyse systemic configurations.

Table 14: Data analysis methodologies used by the configurational perspective

\begin{tabular}{|c|c|c|c|c|c|c|c|c|c|c|c|c|}
\hline \multirow{3}{*}{$\begin{array}{l}\text { Data } \\
\text { analysis } \\
\text { method- } \\
\text { ologies }\end{array}$} & \multicolumn{4}{|c|}{ Past $(\mathrm{N}=72)$} & \multicolumn{4}{|c|}{ Present $(\mathrm{N}=81)$} & \multicolumn{4}{|c|}{ Future $(\mathrm{N}=92)$} \\
\hline & \multirow{2}{*}{$\%$} & \multirow{2}{*}{$M(S D)$} & \multicolumn{2}{|c|}{ ANOVA } & \multirow{2}{*}{$\%$} & \multirow{2}{*}{$M(S D)$} & \multicolumn{2}{|c|}{ ANOVA } & \multirow{2}{*}{$\%$} & \multirow{2}{*}{$M(S D)$} & \multicolumn{2}{|c|}{ ANOVA } \\
\hline & & & $\mathrm{F}$ & Sig. & & & $\mathrm{F}$ & Sig. & & & $\mathrm{F}$ & Sig. \\
\hline Qualitative & $51.4 \%$ & $\begin{array}{c}2.29 \\
(1.982) \\
\end{array}$ & 1.154 & 0.333 & $46.9 \%$ & $\begin{array}{c}2.40 \\
(1.979) \\
\end{array}$ & 1.697 & 0.137 & $57.6 \%$ & $\begin{array}{c}2.62 \\
(2.021) \\
\end{array}$ & 0.571 & 0.722 \\
\hline Univariate & $40.3 \%$ & $\begin{array}{c}1.43 \\
(1.798) \\
\end{array}$ & 0.980 & 0.431 & $42.0 \%$ & $\begin{array}{c}1.36 \\
(1.698) \\
\end{array}$ & 0.609 & 0.693 & $42.4 \%$ & $1.30(1609)$ & 1.414 & 0.220 \\
\hline Multivariate & $54.2 \%$ & $\begin{array}{c}2.18 \\
(2.112)\end{array}$ & 0.557 & 0.733 & $56.8 \%$ & $\begin{array}{c}2.25 \\
(2.089)\end{array}$ & 2.860 & 0.016 & $57.6 \%$ & $\begin{array}{c}2.41 \\
(2.180)\end{array}$ & 1.357 & 0.242 \\
\hline
\end{tabular}




\section{Contextual perspective}

The contextual perspective proposes a reconsideration of the relationship between the strategic HRM system and its context (Brewster 1999). Drawing on contingent studies, the contextual perspective re-analyses environmental influences, not as unidirectional pressures, as those papers did, but integrating human resource strategies into a social macrosystem, which both influences and is influenced by managerial decisions (Brewster/Bournois 1991; Brewster, Hegewisch/Lockart 1991; Brewster 1993, 1995, 1999). Therefore, strategies must be explained not only through their contribution to organizational performance, but also through their influence on internal aspects of the firm (workforce satisfaction, turnover, conflicts, etc.) and their effects on the environment in which they are implemented. Strategic HRM will reinforce firm success to the extent that it helps to integrate and legitimate the organization in its environment, a condition that, as Institutional Theory has pointed out, is directly linked to firm survival (Powell/DiMaggio 1991).

This perspective introduces an important shift in the point of view, proposing a broader descriptive explanation of strategic HRM. It is an explicit aim of contextual authors to provide models applicable to any environment, encompassing the particularities of different industrial and geographical contexts (Brewster 1999). Although it is nowadays applied to many different environments, it can be said that the contextual perspective was created to explain the distinctiveness of European organizational context. This was one of the main objectives of the Price Waterhouse Cranfield Project, which was one of the main drivers of this approach in its first years of development.

The change proposed by the contextual perspective is visible, fundamentally in the reconsideration of three basic aspects: the nature of human resources, the level of analysis and the actors involved in this function (Brewster 1999). (1) Contextual models propose an expansion of the concept of HRM to encompass factors that have been traditionally underestimated, such as a firm's relationships with Public Administration and Unions, and other social and institutional determinants (Legge 1989; Gaugler 1988; Albert 1989; Guest 1990; Pieper 1990; Bournois 1991; Brewster/ Bournois 1991). In contrast to previous perspectives, these variables are considered as part of the concept of strategic HRM, which, following authors such as Brewster (1999), must be considered as a reality that exceeds the boundaries of the organization. This reconsideration of the nature of HRM also influences the position of this function within the organization. Following the conclusions of Brewster and Hoogendoorn (1992), Brewster and Soderstrom (1994) or Brewster, Larsen, and Maryhofer (1997) it can be said that HRM is no longer an exclusive responsibility of personnel managers, but also of other managers, especially line directors. (2) Considering the above, it is easy to understand that the contextual framework also proposes a change in the level of analysis. The contextual framework takes neither a subfunctional nor a systemic point of view, adopting the wider scope of the social environment in which HRM strategies are formulated and implemented. Therefore, it is possible to find many European contextual works that try to analyse the influence of different national environments in the management of human resources (Brewster 1999). (3) Under these new premises, it is also necessary to reconsider the range of stakeholders that 
take part in managerial decisions. The contextual perspective also considers that many actors are involved in the formulation and implementation of human resource strategies. These stakeholders are not only internal, but also external to the organization, so the degree to which they influence and are influenced by human resource policies must be considered (Tyson 1997). Therefore, mutuality of interests is seen as a necessary requisite to assure the survival of the organization in the long term (Brewster 1995).

The theoretical foundations of the contextual perspective seem to begin at a different point. In contrast to the three previous perspectives, that shared common underpinnings, their reconsideration of the HRM model is much closer to industrial relations literature, which implies a criticism of many of the premises of the rational and normative theory (Brewster 1993, 1995, 1999; Sparrow/Hiltrop 1994).

The methodologies used by contextual empirical analysis are determined by their descriptive purpose. Techniques are based almost exclusively in simple statistical analysis, developed through the study of means and standard deviations (Brewster/ Bournois 1991). The application of more complex quantitative and qualitative tools could allow a deeper analysis of social, political and legal influences, as well as a better understanding of the effects of human resource decisions on the social and organizational environment (Gratton et al. 1999). It would also make contextual conclusions comparable to those coming from the other perspectives, enriching the traditional normative and prescriptive approach with another focused on social issues and characterized by a more descriptive objective.

The value added by the contextual perspective lies in its analysis of the social dimensions of strategic HRM. The function is presented as an integral part of the reality in which it is developed, as a contextual framework, and not just as a simple contingency variable. The manager's decision autonomy depends heavily on the social, cultural and institutional pressures under which the strategic choices are taken, as well as by governmental and union policies. Under this new way of understanding HRM (Figure 4), strategies contribute to a firm's success and survival not only by providing performance, but also by helping to integrate and legitimate the organization in the environment in which it operates. The main limitation of this closed model comes from its empirical development (Beaumont 1992). The many series of data extracted from surveys such as those provided by the Price Waterhouse Cranfield Project were analysed, as we have said, using simple statistics, mainly descriptive, perhaps because of the explicative objective of this research perspective (Filella 1991). On the other hand, and although the contextual perspective explicitly adopts an inductive logic of research (Brewster 1991), qualitative methods are rarely used to test their models.

Drawing on the data obtained from the questionnaire, we can deduce that the contextual perspective has been, is, and will be, a crucial pathway of development of SHRM research. Table 15 shows that it has been as broadly adopted as the contingent perspective, the other pillar of the discipline. Similarly, human resource strategies attract the attention of the majority of contextual scholars (Table 16), and again ANOVA results are non-significant, although the models that they propose to explain them introduce a radical change in the point of view. 
Figure 4: Contextual perspective (Source: own elaboration from Hendry/Pettigrew (1986, 1990) and Brewster/Bournois (1991))

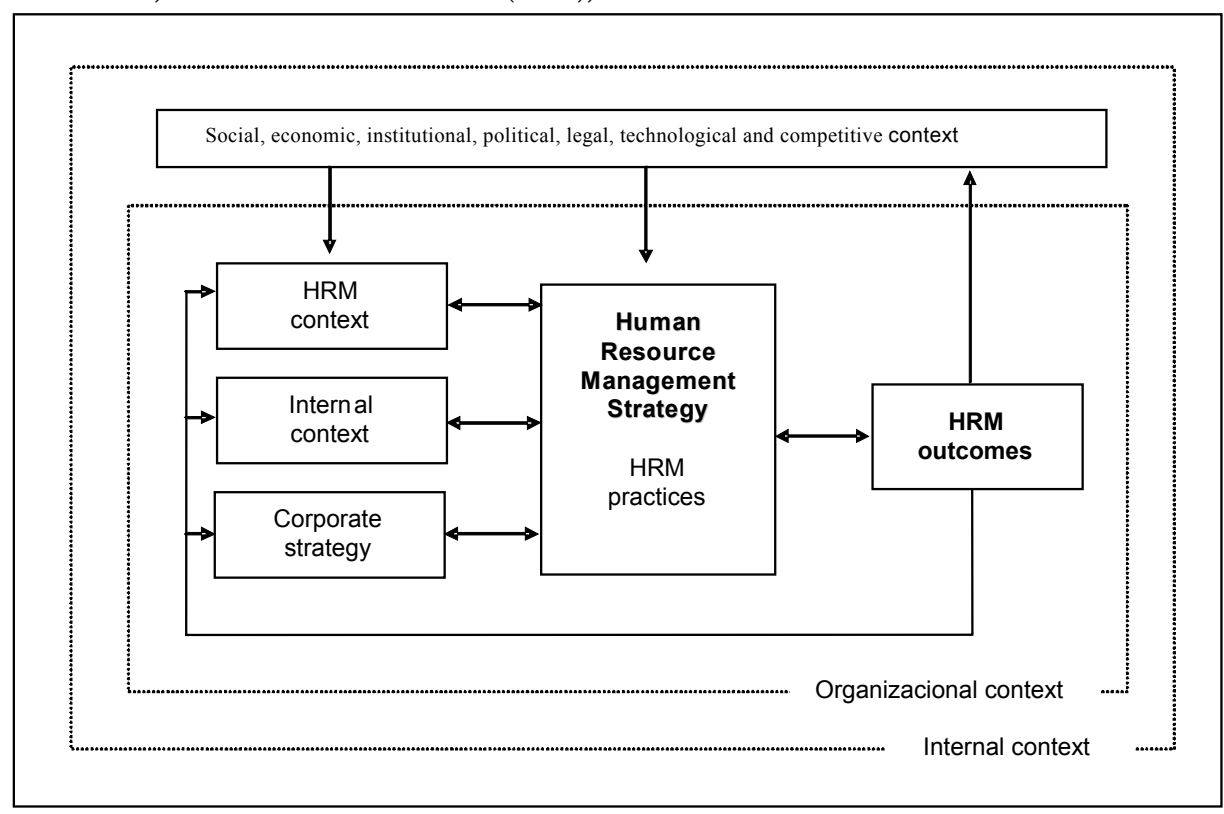

Table 15: Use of the contextual perspective $(\mathrm{N}=223)$

\begin{tabular}{|l|c|c|c|}
\hline Configurational perspective & Past use & Present use & Future use \\
\hline Low level of use & $45.8 \%$ & $37.1 \%$ & $36.7 \%$ \\
\hline Medium level of use & $21.1 \%$ & $17.9 \%$ & $14.3 \%$ \\
\hline High level of use & $33.1 \%$ & $44.0 \%$ & $48.9 \%$ \\
\hline
\end{tabular}

Table 16: Main areas of interest of contextual scholars

\begin{tabular}{|c|c|c|c|c|c|c|c|c|c|c|c|c|}
\hline & \multicolumn{4}{|c|}{ Past $(\mathrm{N}=121)$} & \multicolumn{4}{|c|}{ Present $(\mathrm{N}=138)$} & \multicolumn{4}{|c|}{ Future $(\mathrm{N}=141)$} \\
\hline & \multirow{2}{*}{$\%$} & \multirow{2}{*}{$M(S D)$} & \multicolumn{2}{|c|}{ ANOVA } & \multirow{2}{*}{$\%$} & \multirow{2}{*}{$M(S D)$} & \multicolumn{2}{|c|}{ ANOVA } & \multirow{2}{*}{$\%$} & \multirow{2}{*}{$M(S D)$} & \multicolumn{2}{|c|}{ ANOVA } \\
\hline & & & $\mathrm{F}$ & Sig. & & & $\mathrm{F}$ & Sig. & & & $\mathrm{F}$ & Sig. \\
\hline $\begin{array}{l}\text { Staffing, } \\
\text { recruit- } \\
\text { ment } \\
\text { and } \\
\text { selection }\end{array}$ & $44.2 \%$ & $\begin{array}{c}1.73 \\
(1.909)\end{array}$ & 1.804 & 0.113 & $46.7 \%$ & $\begin{array}{c}1.63 \\
(1.835)\end{array}$ & 0.057 & 0.998 & $45.4 \%$ & $\begin{array}{c}1.67 \\
(1.918)\end{array}$ & 1.785 & 0.117 \\
\hline $\begin{array}{l}\text { Compen } \\
\text { sation }\end{array}$ & $37.5 \%$ & $\begin{array}{c}1.31 \\
(1.738)\end{array}$ & 1.394 & 0.228 & $38.0 \%$ & $\begin{array}{c}1.36 \\
(1.806)\end{array}$ & 1.302 & 0.264 & $43.3 \%$ & $\begin{array}{c}1.50 \\
(1.811)\end{array}$ & 1.355 & 0.243 \\
\hline Training & $49.2 \%$ & $\begin{array}{c}1.76 \\
(1.843)\end{array}$ & 3.884 & 0.002 & $54.0 \%$ & $\begin{array}{c}1.89 \\
(1.846)\end{array}$ & 2.161 & 0.060 & $51.8 \%$ & $\begin{array}{c}2.01 \\
(1.993)\end{array}$ & 1.563 & 0.172 \\
\hline $\begin{array}{l}\text { Sociali- } \\
\text { zation }\end{array}$ & $39.2 \%$ & $\begin{array}{c}1.48 \\
(1.801)\end{array}$ & 3.411 & 0.005 & $34.6 \%$ & $\begin{array}{c}1.26 \\
(1.739)\end{array}$ & 1.506 & 0.189 & $39.3 \%$ & $\begin{array}{c}1.40 \\
(1.820)\end{array}$ & 0.896 & 0.427 \\
\hline $\begin{array}{l}\text { Motiva- } \\
\text { tion }\end{array}$ & $52.9 \%$ & $\begin{array}{c}2.26 \\
(1.963) \\
\end{array}$ & 1.925 & 0.091 & $52.2 \%$ & $\begin{array}{c}2.24 \\
(1.957) \\
\end{array}$ & 1.685 & 0.139 & $51.8 \%$ & $\begin{array}{c}2.23 \\
(1.894) \\
\end{array}$ & 0.881 & 0.495 \\
\hline $\begin{array}{l}\text { Human } \\
\text { Re- } \\
\text { source } \\
\text { Strate- } \\
\text { gies }\end{array}$ & $65.5 \%$ & $\begin{array}{c}2.61 \\
(1.979)\end{array}$ & 5.730 & 0.000 & $74.5 \%$ & $\begin{array}{c}2.98 \\
(1.904)\end{array}$ & 4.339 & 0.001 & $75.2 \%$ & $\begin{array}{c}3.20 \\
(1.939)\end{array}$ & 2.382 & 0.040 \\
\hline
\end{tabular}


From the data included in Table 17 it is also possible to extract some interesting conclusions about the evolution of the contextual approach. When they were asked about the theories used to develop their models in the past, contextual scholars gave relatively lower importance to classical strategic theories, such as the Resource-Based View of the Firm, but if we consider responses for present and future, this trend changes and, surprisingly, the theoretical foundations of this approach do not differ much from the other approaches. We can observe how the Behavioural Perspective receives the highest valuation, together with the Resource-Based View of the Firm. Results for the F-statistic in both cases are highly non-significant, so we can assume that the contextual perspective is converging to the general tendency. For the interest of future research, means are different in the case of Open Systems, Social Capital, Resource Dependency and Institutional theories, which are directly related to the explanation of environmental issues. Therefore, we can conclude that the theoretical foundations of the contextual framework have opened its explanation of the social dimension of HR strategies to receive new propositions from those theories that have been traditionally applied in SHRM research.

Table 17: Theoretical foundations of the contextual perspective

\begin{tabular}{|c|c|c|c|c|c|c|c|c|c|c|c|c|}
\hline & \multicolumn{4}{|c|}{ Past $(\mathrm{N}=121)$} & \multicolumn{4}{|c|}{ Present $(\mathrm{N}=138)$} & \multicolumn{4}{|c|}{ Future $(\mathrm{N}=141)$} \\
\hline & \multirow{2}{*}{$\%$} & \multirow{2}{*}{$M(S D)$} & \multicolumn{2}{|c|}{ ANOVA } & \multirow{2}{*}{$\%$} & \multirow{2}{*}{$M(S D)$} & \multicolumn{2}{|c|}{ ANOVA } & \multirow{2}{*}{$\%$} & \multirow{2}{*}{$M(S D)$} & \multicolumn{2}{|c|}{ ANOVA } \\
\hline & & & $\mathrm{F}$ & Sig. & & & $\mathrm{F}$ & Sig. & & & $\mathrm{F}$ & Sig. \\
\hline $\begin{array}{l}\text { Resource- } \\
\text { Based } \\
\text { View }\end{array}$ & $59.5 \%$ & $\begin{array}{c}2.16 \\
(1.775)\end{array}$ & 1.221 & 0.300 & $68.8 \%$ & $\begin{array}{c}2.46 \\
(1.768)\end{array}$ & 0.637 & 0.672 & $73.0 \%$ & $\begin{array}{c}2.72 \\
(1.785)\end{array}$ & 0.963 & 0.441 \\
\hline $\begin{array}{l}\text { Behav- } \\
\text { ioural Per- } \\
\text { spective }\end{array}$ & $79.3 \%$ & $\begin{array}{c}3.13 \\
(1.775)\end{array}$ & 2.513 & 0.031 & $76.1 \%$ & $\begin{array}{c}2.91 \\
(1.771)\end{array}$ & 0.475 & 0.794 & $77.3 \%$ & $\begin{array}{c}2.97 \\
(1.789)\end{array}$ & 0.572 & 0.722 \\
\hline $\begin{array}{l}\text { Open Sys- } \\
\text { tems The- } \\
\text { ory }\end{array}$ & $59.5 \%$ & $\begin{array}{c}2.22 \\
(1.877)\end{array}$ & 5.655 & 0.000 & $37.2 \%$ & $\begin{array}{c}2.11 \\
(1.803)\end{array}$ & 4.797 & 0.000 & $60.3 \%$ & $\begin{array}{c}2.17 \\
(1.812)\end{array}$ & 5.328 & 0.000 \\
\hline $\begin{array}{l}\text { Agency } \\
\text { and Trans- } \\
\text { action } \\
\text { Costs }\end{array}$ & $40.5 \%$ & $\begin{array}{c}1.52 \\
(1.737)\end{array}$ & 1.599 & 0.162 & $42.0 \%$ & $\begin{array}{c}1.49 \\
(1.662)\end{array}$ & 3.129 & 0.009 & $44.7 \%$ & $\begin{array}{c}1.55 \\
(1.713)\end{array}$ & 1.513 & 0.187 \\
\hline $\begin{array}{l}\text { Human } \\
\text { Capital } \\
\text { Theory }\end{array}$ & $49.6 \%$ & $\begin{array}{c}1.73 \\
(1.732)\end{array}$ & 1.352 & 0.244 & $61.6 \%$ & $\begin{array}{c}2.14 \\
(1.748)\end{array}$ & 0.872 & 0.501 & $63.8 \%$ & $\begin{array}{c}2.30 \\
(1.848)\end{array}$ & 1.656 & 0.146 \\
\hline $\begin{array}{l}\text { Social } \\
\text { Capital } \\
\text { Theory }\end{array}$ & $39.7 \%$ & $\begin{array}{c}1.24 \\
(1.438)\end{array}$ & 2.515 & 0.031 & $49.3 \%$ & $\begin{array}{c}1.60 \\
(1.641)\end{array}$ & 2.672 & 0.023 & $54.6 \%$ & $\begin{array}{c}1.98 \\
(1.857)\end{array}$ & 4.183 & 0.001 \\
\hline $\begin{array}{l}\text { Resource } \\
\text { Depend- } \\
\text { ency The- } \\
\text { ory }\end{array}$ & $48.8 \%$ & $\begin{array}{c}1.49 \\
(1.528)\end{array}$ & 6.025 & 0.000 & $46.4 \%$ & $\begin{array}{c}1.55 \\
(1.608)\end{array}$ & 2.905 & 0.015 & $46.1 \%$ & $\begin{array}{c}1.61 \\
(1.681)\end{array}$ & 3.874 & 0.002 \\
\hline $\begin{array}{l}\text { Institutional } \\
\text { Theory }\end{array}$ & $49.6 \%$ & $\begin{array}{c}1.82 \\
(1.784)\end{array}$ & 10.205 & 0.000 & $55.1 \%$ & $\begin{array}{c}2.05 \\
(1.865)\end{array}$ & 7.605 & 0.000 & $57.4 \%$ & $\begin{array}{c}2.21 \\
(1.900)\end{array}$ & 7.390 & 0.000 \\
\hline
\end{tabular}

Compared to the rest of the approaches, we observe that the contextual perspective has experienced relatively lower growth in the use of multivariate techniques (Table 18). Contrary to what we might have expected, univariate techniques also receive a lower valuation, although contextual models have an explicative purpose. On the other hand, qualitative analyses are now used much more than in the past and, according to our data, they will be the most important methodology for future contextual re- 
search. This confirms that an inductive mode of theorizing characterized the origins of explicative contextual models.

Table 18: Data analysis methodologies used by the configurational perspective

\begin{tabular}{|c|c|c|c|c|c|c|c|c|c|c|c|c|}
\hline & \multicolumn{4}{|c|}{ Past $(\mathrm{N}=121)$} & \multicolumn{4}{|c|}{ Present $(\mathrm{N}=128)$} & \multicolumn{4}{|c|}{ Future $(\mathrm{N}=141)$} \\
\hline & \multirow{2}{*}{$\%$} & \multirow{2}{*}{$M(S D)$} & \multicolumn{2}{|c|}{ ANOVA } & \multirow{2}{*}{$\%$} & \multirow{2}{*}{$M(S D)$} & \multicolumn{2}{|c|}{ ANOVA } & \multirow{2}{*}{$\%$} & \multirow{2}{*}{$M(S D)$} & \multicolumn{2}{|c|}{ ANOVA } \\
\hline & & & $\mathrm{F}$ & Sig. & & & $\mathrm{F}$ & Sig. & & & $F$ & Sig. \\
\hline $\begin{array}{l}\text { Qua- } \\
\text { litati- } \\
\text { ve }\end{array}$ & $47.1 \%$ & $\begin{array}{c}2.57 \\
(2.122)\end{array}$ & 5.059 & 0.000 & $50.7 \%$ & $\begin{array}{c}2.53 \\
(2.022)\end{array}$ & 2.387 & 0.039 & $58.2 \%$ & $\begin{array}{c}2.89 \\
(2.035)\end{array}$ & 2.854 & 0.016 \\
\hline $\begin{array}{l}\text { Uni- } \\
\text { varia- } \\
\text { te }\end{array}$ & $35.5 \%$ & $\begin{array}{c}1.23 \\
(1.731)\end{array}$ & 0.318 & 0.902 & $34.1 \%$ & $\begin{array}{c}1.12 \\
(1.648)\end{array}$ & 0.419 & 0.835 & $34.0 \%$ & $\begin{array}{c}1.11 \\
(1.617)\end{array}$ & 0.659 & 0.655 \\
\hline $\begin{array}{l}\text { Multi } \\
\text { va- } \\
\text { riate }\end{array}$ & $46.3 \%$ & $\begin{array}{c}1.89 \\
(2.124)\end{array}$ & 0.727 & 0.604 & $45.7 \%$ & $\begin{array}{c}1.89 \\
(2.137)\end{array}$ & 0.777 & 0.568 & $47.5 \%$ & $\begin{array}{c}2.05 \\
(2.208)\end{array}$ & 0.421 & 0.834 \\
\hline
\end{tabular}

\section{Summary/conclusions}

From the review of the literature and the data we obtained from our questionnaire, we can conclude that the state of the art in SHRM can be described by four research perspectives that represent four different modes of theorizing HR contributions to performance. Nevertheless, empirical analysis has also highlighted several complementarities, which show that the different perspectives are not as disconnected as we expected. We have seen how the universalistic perspective represents the easiest way to analyse this relationship, assuming that it is possible to find optimal Best Human Resource Practices. To identify them the universalistic perspective defines linear relationships between HR and performance that one can generalize to the entire population, normally drawing on Behavioural, Resource-Based and, more recently, Human Capital paradigms. On the other hand, contingent analysis goes a step further, completing HR performance models with a third set of moderating variables. It has been argued that HR strategies and practices will not contribute to performance if they do not fit a firm's strategy and organizational conditions. Drawing on universalistic and contingent perspectives, configurational models propose an in-depth analysis of the internal dynamics of HR strategies, arguing that only consistent sets of practices will reinforce organizational performance in the long term. As in the previous perspectives, configurational propositions have been developed mainly from the Resource-Based and Behavioural approaches, which seem to be the main theoretical pillars of the discipline. Nevertheless, our data also highlight the importance of Systems Theory for configurational purposes. This general paradigm provides a useful framework to describe internally consistent systemic constructions. Finally, the contextual perspective maintains that, as social institutions, organizations need to integrate themselves in the social context in which they operate. Thus, the environment is reconsidered and defined as a macroframework that both influences and is influenced by management decisions. To effectively support organizational sustainability, HRM must help the firm to achieve social legitimacy, so its effects must not only be measured in terms of performance, but also considering their external consequences and their emphasis on objectives common to all stakeholders. Although in its origins, this perspective was grounded on an industrial relations approach, our data show that current contextual models are 
progressively incorporating inputs from traditional strategic and HRM theories. It can be said that the contextual perspective, traditionally inductive and descriptive, and the contingent approach (much more deductive and prescriptive) are starting to share paradigms and methods in their complementary explanations of the link between the HRM system and its environment.

Despite the evident differences between the universalistic, contingent, configurational and contextual approaches, we can observe that each perspective complements the others by adding constructs, variables or relationships not considered by those others (Table 19). Integrating their main propositions, more complex models can be defined, enriching our understanding of HRM strategies with new dimensions (Figure 5). This discipline, as those others that have the human being as their central object of study, require multidisciplinary, multiparadigmatic, and multidimensional analytical frameworks. For that reason, much seems to be gained from integrating perspectives. It is especially interesting to observe how, balancing the contributions and main limitations of universalistic, contingent, configurational and contextual models, it is possible to extract an integrative model, which brings together their main propositions and that, in general terms, represents our common understanding of the complex phenomenon of strategic HRM.

Table 19: Main contributions and limitations of the four research perspectives (Source: own elaboration)

\begin{tabular}{|c|c|c|c|c|}
\hline & $\begin{array}{l}\text { Universalistic Perspec- } \\
\text { tive }\end{array}$ & $\begin{array}{l}\text { Contingent Perspec- } \\
\text { tive }\end{array}$ & $\begin{array}{l}\text { Configurational Perspec- } \\
\text { tive }\end{array}$ & $\begin{array}{l}\text { Contextual Perspec- } \\
\text { tive }\end{array}$ \\
\hline 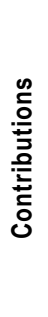 & $\begin{array}{l}\text { Demonstration of the im- } \\
\text { portance of human capi- } \\
\text { tal in organizations. } \\
\text { High level of statistical } \\
\text { significance in the test of } \\
\text { this proposition. }\end{array}$ & $\begin{array}{l}\text { Inclusion of other vari- } \\
\text { ables that mediate the } \\
\text { relationship between } \\
\text { HRM and performance. } \\
\text { Stronger theoretical } \\
\text { basis. }\end{array}$ & $\begin{array}{l}\text { Internal analysis of the } \\
\text { HRM system. } \\
\text { Consideration of synergy } \\
\text { and interdependence be- } \\
\text { tween the different ele- } \\
\text { ments of the system. } \\
\text { Assumption that different } \\
\text { HRM configurations can be } \\
\text { equally efficient. }\end{array}$ & $\begin{array}{l}\text { Introduction of the so- } \\
\text { cial dimension of HRM. } \\
\text { Integration of the HRM } \\
\text { system in a macroso- } \\
\text { cial context. } \\
\text { Reconsideration of } \\
\text { manager's autonomy of } \\
\text { decision. } \\
\text { Large series of data. }\end{array}$ \\
\hline 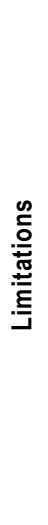 & $\begin{array}{l}\text { Deficient theoretical } \\
\text { foundations. } \\
\text { Narrow objectives. } \\
\text { Mechanistic and rational } \\
\text { explanations. } \\
\text { Conceptual limitations in } \\
\text { the establishment of } \\
\text { causal relationships. } \\
\text { Performance measures } \\
\text { based exclusively on fi- } \\
\text { nancial indicators. } \\
\text { Strategic change not ex- } \\
\text { plained. } \\
\text { HRM considered as a } \\
\text { "black box". }\end{array}$ & $\begin{array}{l}\text { Micro-orientation. } \\
\text { The statistical tech- } \\
\text { niques mainly used } \\
\text { (regressions) lead to } \\
\text { universalistic conclu- } \\
\text { sions. } \\
\text { Excessive emphasis on } \\
\text { "fit" issues. } \\
\text { No consideration of po- } \\
\text { litical variables. } \\
\text { HRM considered as a } \\
\text { "black box". }\end{array}$ & $\begin{array}{l}\text { The definition of manage- } \\
\text { ment patterns is a simplifi- } \\
\text { cation of reality. } \\
\text { More complex methodolo- } \\
\text { gies required. } \\
\text { Deficient empirical founda- } \\
\text { tions. }\end{array}$ & $\begin{array}{l}\text { Deficient empirical } \\
\text { treatment, based } \\
\text { mainly on descriptive } \\
\text { statistical techniques. } \\
\text { Theoretical foundations } \\
\text { differ from the rest of } \\
\text { perspectives, and are } \\
\text { based mainly an Indus- } \\
\text { trial Relations ap- } \\
\text { proach. }\end{array}$ \\
\hline
\end{tabular}


Figure 5: Building an integrative model (Source: own elaboration)

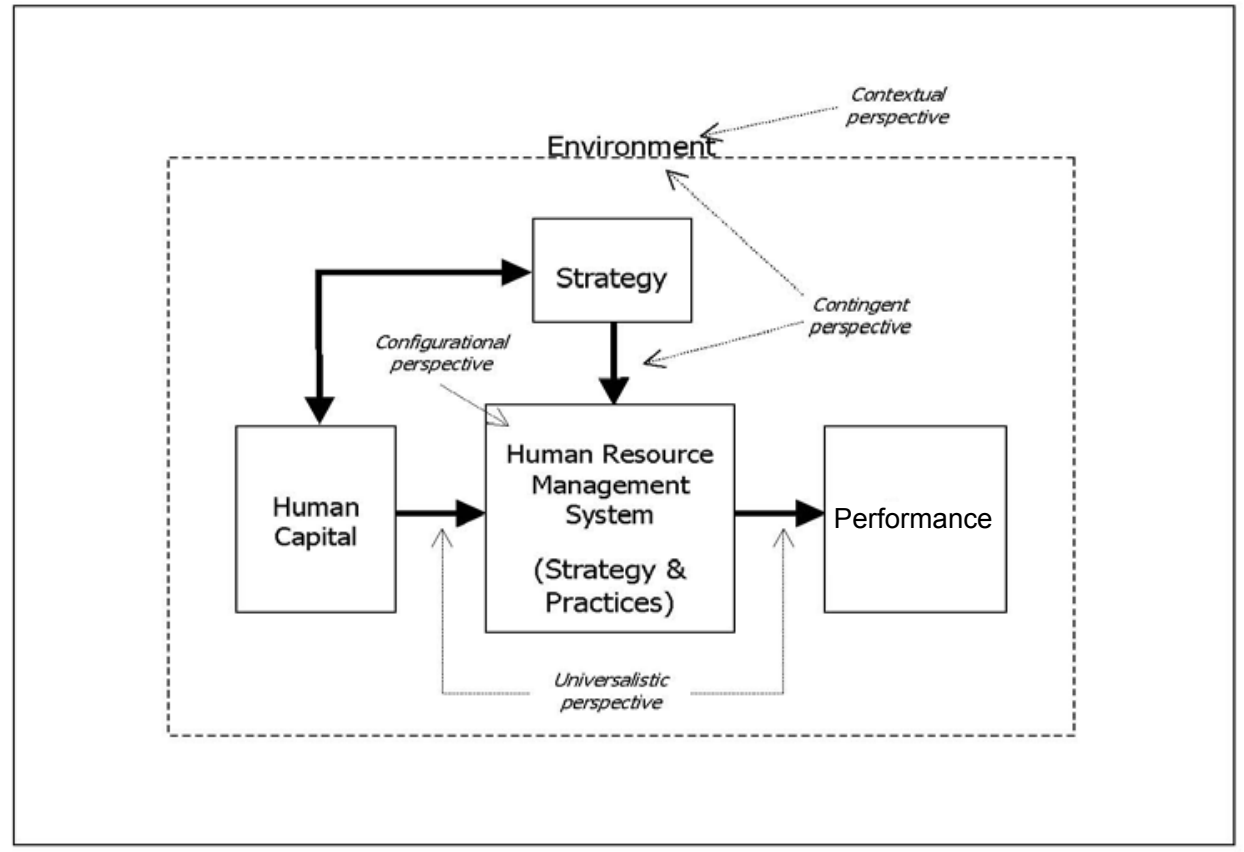

\section{References}

Ackerman, K. F. (1986): A contingency model of HRM Strategy - empirical research findings revisited. In: Management Forum, $6: 65-83$.

Albert, F. J. (1989): Les resources humaines, atout stratégique. Editions L’harmattan.

Arthur, J. B. (1994): Effects of human resource systems on manufacturing performance. In: Academy of Management Journal, 37: 670-687.

Bacharach, S. (1989): Organizational theories: Some criteria for evaluation. In: Academy of Management Review, 14: 496-515.

Baird, L./Meshoulam, I. (1984): The HRS Matrix: Managing the Human Resource Function Strategically. In: Human Resource Planning, 7 (1): 1-29.

Balkin, D./Bannister, B. (1993): Explaining pay forms for strategic employee groups in organizations: A resource dependence perspective. In: Journal of Occupational and Organizational Psychology, 66: 139-151.

Beaumont, P. B. (1992): Annual Review Article: 1991. In: British Journal of Industrial Relations, 30(1): 107-125.

Becker, B. E./Gerhart, B. (1996): The impact of human resource management on organizational performance: progress and prospects. In: Academy of Management Journal, 39(4): 779-801.

Becker, B. E./Huselid, M. A./Pickus, P. S./Spratt, M. F. (1997): HR as a source of shareholder value: research and recommendations. In: Human Resource Management, 36(1): 39-47.

Beer, M./Lawrence, P.R./Mill, Q.D./Walton, R.E. (1984): Human Resource Management. New York: The Free Press.

Beer, M./Spector, B./Lawrence, P. R./Mill, Q. D./Walton, R. E. (1985): Managing Human Assets. New York: The Free Press.

Begin, J. P. (1993): Identifying patterns in HRM systems: Lessons learned from organizational theory. In: Research in Personnel and Human Resource Management, supplement 3: 3-20.

Borman, W. C. (1991): Job Behaviour, Performance, and Effectiveness. In: Dunnette, M. D./Hough, L. M. (Eds.): Handbook of Industrial and Organizational Psychology: 271-326. 
Boudreau, J. W./Ramstad, P. M. (1999): Human Resource Metrics: can measures be strategic?. In: Research in Personnel and Human Resources Management, supplement 4: 75-98.

Bournois, F. (1991): La gestion des crades en Europe. Paris: Editions Liaisons.

Boxall, P./Steeneveld, M. (1999): Human resource strategy and competitive advantage: a longitudinal study of engineering consultancies. In: Journal of Management Studies, 36(4): 448-463.

Brewster, C. (1991): The management of expatriates. London: Kogan Page.

Brewster, C. (1993): Developing a 'European' model of Human Resource Management. In: International Journal of Human Resource Management, 4(4): 765-784.

Brewster, C. (1995): Towards a European Model of Human Resource Management. In: Journal of International Business Studies, first quarter: 1-21.

Brewster, C. (1999): Strategic Human Resource Management: the value of different paradigms. In: Management International Review, 39(3): 45-64.

Brewster, C./Hegewisch, A./Lockhart, J. T. (1991): Researching Human Resource Management: Methodology of The Price Waterhouse Cranfield Project on European Trends. In: Personnel Review, 20(6): 36-40.

Brewster, C./Bournois, F. (1991): Human Resource Management: a European Perspective. In: Personnel Review, 20(6): 4-13.

Brewster, C./Hegewisch, A. (1993): A continent of diversity. In: Personnel Management, January: 36-40.

Brewster, C./Hoogendoorn, J. (1992): Human Resource Aspects of Decentralisation and Devolution. In: Personnel Review, 21(1): 4-11.

Brewster, C./Söderström, M. (1994): Human Resources and Line Management, Policy and Practice in European Human Resource Management: The Price Waterhouse Survey. London: Routledge.

Brewster, C./Larsen H. H./Maryhofer, W. (1997): Integration and Assignment: A Paradox in Human Resource Management. In: Journal of International Management, 3(1): 1-23.

Bühner, R. (1997): Increasing Shareholder Value Through Human Asset Management. In: Long Range Planning, 30(5): 710-717.

Burack, E. H./Smith, R. D. (1977): Personnel Management. New York: Wiley Pub.

Butler, J. E./Ferris, G. R./Napier N. K. (1991): Strategy and Human Resource Management. Cincinati: South-western Publishing Co.

Cappelli, P./Neumark, D. (2001): Do 'High-Performance' work practices improve establishment-level outcomes? In: Industrial and Labour Relations Review, 54(4): 737-775.

Cappelli, P./Singh, H. (1992): Integrating strategic human resources and strategic management. In: Lewin, D./Mitchell, O. S./Sherer, P. (Eds.): Research Frontiers in Industrial Relations and Human Resources: 165-192. Madison: Industrial Relations Research Association.

Chadwick, C./Cappelli, P. (1999): Alternatives to strategic generic strategy typologies in strategic human resource management. In: Research in Personnel and Human Resource Management, supplement 4: 1-29.

Chandler, A. D. (1962): Strategy and Structure: chapters in the history of the industrial enterprise. Cambridge, Massachussetts: MIT Press.

Davis, R. C. (1981): Relating human resources management to business strategy. Proceedings of the Human Resource Policy Institute.

De Sáa Pérez, P./García Falcón, J. M. (2002): A resource-based view of human resource management and organizational capabilities development. In: International Journal of Human Resource Management, 13(1): 123-140.

Delery, J. E. (1998): Issues of fit in Strategic Human Resource Management: Implications for research. In: Human Resource Management Review, 8(3): 289-309.

Delery, J. E./Doty, D. H. (1996): Modes of Theorizing in Strategic Human Resource Management: Test of Universalistic, Contingency, and Configurational performance predictions', Academy of Management Journal, 39(4): 802-835.

Delery, J. E./Shaw, J. D. (2001): The strategic management of people in work organizations: review, synthesis, and extension. In: Research in Personnel and Human Resource Management, 20: 165-197.

Devanna, M./Fombrun, C./Tichy, N. (1981): Human Resources Management: A Strategic Perspective. In: Organizational Dynamics, Winter: 51-67.

Dewar, R./Werbel, J. (1979): Universalistic and contingency predictions of employee satisfaction and conflict. In: Administrative Science Quarterly, 24: 426-448.

Doty, D. H./Glick, W. H. (1994): Typologies as a unique form of theory building: Toward improved understanding and modelling. In: Academy of Management Journal 19: $230 \mathrm{ff}$. 
Doty, D. H./Glick, W. H./Huber, G. P. (1993): Fit, equifinality, and organizational effectiveness: a test of two configurational theories. In: Academy of Management Journal, 36: 1196-1250.

Drucker, P. (1968): The practice of management. London: Pan.

Duncan, G./Hoffman, S. (1981): The incidence and wage effects of over education. In: Economics and Education Review, 1: 75-86.

Dyer, L. (1985): Strategic Human Resources Management and Planning. In: Rowland, K. M./Ferris, G. R. (Eds.): Research in Personnel and Human Resource Management: 1-30. Greenwich: JAI Press.

Dyer, L./Reeves, T. (1995): Human Resource Strategies and Firm Performance: What do we know and where do we need to go?. Paper presented to the 10th International Congress of the International Industrial Relations Association, Washington, DC.

Ferris, G. F./Arthur, M. M./Berkson, H. M./Kaplan, D. M./Harrell-Cook, G./Frink, D. D. (1998): Toward a social context theory of the human resource management-organization effectiveness relationship. In: Human Resource Management Review, 8(3): 235-264.

Filella, J. (1991): Is there a Latin Model in the Management of Human Resources?. In: Personnel Review, 20(6): 14-23.

Fombrun, C./Tichy, N./Devanna, M. (1984): Strategic Human Resource Management.. John Wiley and Sons.

Foulkes, F. K. (1975): The expanding role of the personnel function. In: Harvard Business Review, March-April: 146-156.

Galbraith, J./Nathanson, D. (1978): Strategy Implementation: The Role of Structure and Process. St. Paul, MN: West Publishing.

Galosy, J. R. (1983): Meshing human resource planning with strategic business planning: One company's experience. In: Personnel, 60(5): 26-35.

Gaugler, E. (1988): HR Management: An International Comparison. In: Personnel: 24-30.

Gerhart, B. (1999): Human Resource Management and Firm Performance. In: Research in Personnel and Human Resource Management, supplement 4: 31-51.

Gerhart, B./Milkovich, G. T. (1990): Organizational differences in managerial compensation and financial performance. In: Academy of Management Journal, 33: 846-860.

Godard, J. (1997): Whither Strategic Choice: Do Managerial IR Ideologies Matter?. In: Industrial Relations, 36(2): 206-228.

Gómez Mejía, L./Balkin, D.B. (1992): Compensation, organizational strategy, and firm performance. Cincinatti: South-Western.

Gómez Mejía, L./Tosi, H/Hinkin, T. (1987): Managerial control, performance, and executive compensation. In: Academy of Management Journal, 30(1): 51-70.

Gratton, L./Hope-Hailey, V./Stiles, P./Truss, C. (1999): Linking individual performance to business strategy: the people process model. In: Human Resource Management, 38(1): 17-31.

Guest, D. (1989): Personnel and HRM: Can you tell the difference?. In: Personnel Management, 21(1): 48-51.

Guest, D. (1990): Human Resource Management and the American Dream. In: Journal of Management Studies, 27(4): 377-397.

Guest, D. (2001): Human Resource Management: when research confronts theory. In: International Journal of Human Resource Management, 12(7): 1.092-1.106.

Hax, A.C. (1985): A New Competitive Weapon: The Human Resource Strategy. In: Training and Development Journal, 39(5): 76-82.

Hendry, C./Pettigrew, A. (1986): The practice of strategic human resource management. In: Personnel Review, 15(5): 3-8.

Hendry, C./Pettigrew, A. (1990): HRM: An agenda for the 1990s. In: International Journal of Human Resource Management, 1(1): 17-25.

Huselid, M. A. (1993): Estimates of the impact of human resource management practices on turnover and productivity. Paper presented to the Annual Meeting of the Academy of Managament 1993, Atlanta.

Huselid, M. A./Jackson, S. E./Schuler, R. S. (1997): Technical and strategic human resource management effectiveness as determinants of firm performance. In: Academy of Management Journal, 40(1): 171-188.

Jackson, S. E./Schuler, R. S. (1995): Understanding Human Resource Management in the context of organizations and their environments. In: Annual Review of Psychology, 46: 237-264.

Jackson, S. E./Schuler, R. S./Rivero, J. C. (1989): Organizational characteristics as predictors of personnel practices. In: Personnel Psychology, 42: 727-786. 
Jones, G. (1984): Task visibility, free riding, and shirking: explaining the effect of structure and technology on employee behaviors. In: Academy of Management Review, 9: 684-695.

Kelliher, C./Perrett, G. (2001): Business Strategy and approaches to HRM: a case study of new developments in the United Kingdom restaurant industry. In: Personnel Review, 30(4): 421-437.

Keng-Howe Chew, I./Chong, P. (1999): Effects of strategic human resource management on strategic vision. In: International Journal of Human Resource Management, 10(6): 1.031-1.045.

Kerr, J. L. (1985): Diversifications Strategies and Managerial Rewards: An Empirical Study. In: Academy of Management Journal, 28: 155-179.

Kerr, J. L./Jackofsky, E. F. (1989): Aligning managers with strategies: Management development versus selection. In: Strategic Management Journal, 10: 157-170.

Ketchen, D. J./Thomas, J. B./Snow, C. C. (1993): Organizational configurations and performance: A comparison of theoretical approaches. In: Academy of Management Review, 36: 1278-1313.

Khatri, N. (2000): Managing human resource for competitive advantage: a study of companies in Singapore. In: International Journal of Human Resource Management, 11(2): 336-365.

Koch, M. J./McGrath, R. G. (1996): Improving Labor Productivity: Human Resource Management Policies Do Matter. In: Strategic Management Journal, 17: 335-354.

Lado, A. A./Wilson, M. C. (1994): Human Resource Systems and sustained competitive advantage: a competency-based perspective. In: Academy of Management Review 19(4): 699-727.

Legge, K. (1978): Power, Innovation and Problem Solving in Personnel Management. Maidenhead: McGraw-Hill.

Legge, K. (1989): Human Resource management: a critical analysis. In Storey, J. (Ed.): New Perspectives on Human Resource Management. London: Routledge.

Lengnick-Hall, C. A./Lengnick-Hall, C. A. (1988): Strategic human resource management: A review of the literature and a proposed typology. In: Academy of Management Review, 13(3): 454-470.

Lepak, D./Snell, S. (1998): Virtual HR: strategic human resource management in the 21st Century. In: Human Resource Management Review, 8(3): 215-234.

Lepak, D./Snell, S. (1999): The Human Resource Architecture: toward a theory of Human Capital allocation and development. In: Academy of Management Review, 24(1): 31-48.

Lindtroh, J. (1982): How to beat the coming labour shortage. In: Personnel Journal, 61(4): 268-272.

MacDuffie, J. P. (1995): Human resource bundles and manufacturing performance: Organizational logic and flexible production systems in the world auto industry. In: Industrial and Labour Relations Review, 48: 197-221.

Marchington, M./Grugulis, I. (2000): 'Best Practice' human resource management: perfect opportunity or dangerous illusion. In: International Journal of Human Resource Management, 11(6): 1.104-1.124.

McMahan, G. C./Virick, M./Wright, P. M. (1999): Alternative theoretical perspectives for strategic human resource management revisited: progress, problems and prospects. In: Research in Personnel and Human Resources Management, supplement 4: 99-122.

Meyer, J. W./Tsui, A. S./Hinnigs, C. R. (1993): Guest co-editor's introduction: Configurational approaches to organizational analysis. In: Academy of Management Journal, 36: 1.175-1.195.

Miles, R./Snow, C. (1978): Organizational Structure, Strategy and Process. New York: McGraw-Hill.

Miles, R./Snow, C. (1984): Designing Strategic Human Resource Systems. In: Organizational Dynamics, Summer: 36-52.

Miller, E. L. (1989): Strategic HRM: What it is and what it isn't. In: Personnel Management, February: 46-52.

Miller, M./Friesen, P. H. (1984): Organizations: a quantum view. Englewood Cliffs, New Jersey: Prentice-Hall.

Niniger, J. R. (1980): Human resources and strategic planning: a vital link. In: Optimum, 11(4): 33-46.

Osterman, P. (1994): How common is workplace transformation and who adopts it?. In: Industrial and Labor Relations Review, 47: 173-188.

Peck, S. R. (1994): Exploring the link between organizational strategy and the employment relationship: the role of human resources policies. In: Journal of Management Studies, 31(5): 715-736.

Pfeffer, J. (1994): Competitive advantage through people: Unclosing the power of the work force. Boston: Harvard Business School Press.

Pfeffer, J./Cohen, Y. (1984): Determinants of Internal Labour Markets in Organizations. In: Administrative Science Quarterly, 29: 550-572.

Pfeffer, J./Davis-Blake, A. (1987): Understanding organizational wage structure: A resource dependence approach. In: Academy of Management Journal, 30: 437-455. 
Pfeffer, J./Langton, N. (1988): Wage inequality and the organization of work: the case of academic departments. In: Administrative Science Quarterly, 33: 588-606.

Pieper, R. (1990): Human Resource Management: an International Comparison. Berlin: De Gruyter.

Powell, W./DiMaggio, P. (1991): The New Institutionalism in organizational analysis. Chicago: The University of Chicago Press.

Rhodes, D. W. (1988 a): Can HR respond to Corporate Strategy?. In: The Journal of Business Strategy, 9(2): 57-59.

Rhodes, D. W. (1988 b): Employees-Strategy Makers or Breakers. In: The Journal of Business Strategy, 9(4): 55-58.

Richard, O. C./Johnson, N. B. (2001): Strategic human resource management effectiveness and firm performance. In: International Journal of Human Resource Management, 12(2): 299-310.

Rogers, E. W./Wright, P. M. (1998): Measuring organizational performance in strategic human resource management: problems, prospects and performance information markets. In: Human Resource Management Review, 8(3): 311-331.

Romero Romero, M. G./Valle Cabrera, R. (2001): Strategy and managers compensation: the Spanish case. In: International Journal of Human Resource Management, 12(2): 218-242.

Rowland, K. M./Summers, S. L. (1981): Human resource planning: a second look. In: Personnel Administrator, 26(12): 73-80.

Rumberger, R. W. (1987): The impact of surplus schooling on productivity and earnings. Journal of Human Resources, 22: 24-50.

Russ, C. F. Jr. (1982): Manpower planning systems: Part II. In: Personnel Journal: 119-123.

Russell, C. G./Terborg, J. R./Powers, M. L. (1985): Organizational productivity and organizational level training and support. In: Personnel Psychology, 38: 849-863.

Schoonhoven, C. B. (1981): Problems with contingency theory: testing assumptions hidden within the language of contingency theory. In: Administrative Science Quarterly, 26: 349-377.

Schuler, R. S. (1981): Personnel and Human Resource Management. St. Paul: Minessotta.

Schuler, R. S./Jackson, S. E. (1987a): Linking Competitive Strategies with Human Resource Management Practices. In: Academy of Management Executive, 1(3): 207-219.

Schuler, R. S./Jackson, S. E. (1987b): Organizational Strategy and Organization Level as Determinants of Human Resource Management Practices. In: Human Resource Planning, 10(3): 125-141.

Schultz, T. W. (1971): Investment in Human Capital. The role of education and of research. New York:: The Free Press.

Shafer, R. A./Dyer, L./Kilty, J./Amos, J./Ericksen, J. (2001): Crafting a Human Resource Strategy to foster organizational agility: a case study. In: Human Resource Management, 40(3): 197-211.

Sherer, P. D./Leblevici, H. (2001): Bringing variety and change into strategic human resource management research. In: Research in Personnel and Human Resource Management, 20: 199-230.

Slocum, J. W./Cron, W. L./Hansen, R. W./Rawlings, S. (1985): Business Strategy and the Management of Plateaued Employees. In: Academy of Management Journal, 28: 133-154.

Snell, S. (1992): A test of Control Theory in Strategic Human Resource Management: the mediating effect of administrative information. In: Academy of Management Journal, 35(2): 292-327.

Snell, S. A./Dean, J. W. (1992): Integrated manufacturing and human resource management: a human capital perspective. In: Academy of Management Journal, 35: 467-504.

Snow, C. C./Thomas, J. B. (1994): Field research methods in strategic management: contributions to theory building and testing. In: Journal of Management Studies. 31(4): 457-480.

Sparrow, P./Hiltrop, J. M. (1994): European Human Resource Management in Transition. London: Prentice-Hall.

Sweet, J. (1982): How manpower development can support your strategic plan. In: Journal of Business Strategy, 3(1): 77-81.

Terpstra, D. E./Rozell, E. J. (1993): The relationship of staffing practices to organizational level measures of performance. In: Personnel Psychology, 46: 27-28.

Tichy, N./Fombrun, C./Devanna, M. (1982): Strategic Human Resource Management. In: Sloan Management Review, 23(2): 47-61.

Tosi, H./Gómez Mejía, L. R. (1989): The decoupling of CEO pay and performance: an agency theory perspective. In: Administrative Science Quarterly, 34: 169-183. 
Tosi, H./Gómez Mejía, L.R. (1994): Compensation, monitoring and firm performance. In: Academy of Management Journal, 37(4): 1.002-1.016.

Tsang, M. C. (1987): The impact of underutilization of education on productivity: A case study of the U.S. Bell companies. In: Economics of Education Review, 6: 239-254.

Tubre, T. C./Collins J. M. (2001): Jackson and Schuler (1985): Revisited: A Meta-Analysis of the Relationships Between Role Ambiguity, Role Conflict and Job Performance. In: Journal of Management, 26(1): 155-169.

Tyson, S. (1997): Human resource strategy: a process for managing the contribution of HRM to organizational performance. In: International Journal of Human Resource Management, 8(3): 277-290.

Uhl-Bien, M./Graen, G. B./Scandura, T. A. (2000): Implications of Leader-Member Exchange (LMX): for Strategic Human Resource Management Systems: relationships as social capital for competitive advantage. In: Research in Personnel and Human Resource Management, 18: 137-185.

Van de Ven, A. H./Drazin, R. (1985): The concept of fit in strategy research. In Cummings, L./Staw, B. M. (Eds.): Research in Organizational Behaviour, 7: 333-365. Greenwich, CT. JAI Press.

Venkatraman, N. (1989): The concept of fit in strategy research: Toward verbal and statistical correspondence. In: Academy of Management Review, 14: 423-444.

Venkatraman, N./Prescott, J. E. (1990): Environment-strategy coalignement: An empirical text of its performance implications. In: Strategic Management Journal, 11: 1-23.

Walsh, K. (1985): Trade Union Membership, Methods and Measurement in the European Community. Luxembourg: Eurostat.

Walton, R. E. (1985): Toward a Strategy of Elicitng Employee Commitment Based on Policies of Mutuality. In: Walton, R. E./Lawrence, P. R. (Eds.): HRM trends and challenges. Boston: Harvard Business School Press.

Watson, J. (1977): The Personnel Manager: A study in the sociology of work and employment. London: Routledge and Kegan Paul.

Way-Kwong, F. Y./Priem, R. L./Cycyota, C. S. (2001): The performance effects of human resource managers' and other middle managers' involvement in strategy making under different business-level strategies: the case in Hong Kong. In: International Journal of Human Resource Management, 12(8): 1.325-1.346.

Weber, M. (1949): Objectivity in social science and policy. In: Shis, E. A./Finch, H. A. (Eds. and trans.): Max Weber on the methodology of social sciences: 1-188. Glencoe: Free Press.

Woelfel, J. (1993): Artificial neural networks in policy research: a current assessment. In: Journal of Communications, 43: 62-80.

Wood, S./Albanese, M. T. (1995): Can we speak of a high commitment management on the shop floor? In: Journal of Management Studies, 32(2): 216-247.

Woodward, J. (1965): Industrial organization: Theory and practice. New York: Oxford University Press.

Wright, P. M./McMahan, G. C. (1992): Theoretical Perspectives for Strategic Human Resource Management. In: Journal of Management, 18(2): 295-320.

Wright, P. M./Snell, S. A. (1991): Toward an integrative view of strategic human resource management. In: Human Resource Management Review: 1203-225.

Wright, P. M./Snell, S. A. (1998): Toward a Unifying Framework for Exploring Fit and Flexibility in Strategic Human Resource Management. In: Academy of Management Review, 23(4): 756-772.

Wright, P. M./Dunford, B. B./Snell, S. A. (2001): Human resources and the resource based view of the firm. In: Journal of Management, 27: 701-721.

Wright, P. M./McMahan, G. C./McWilliams, A. (1994): Human Resources and sustained competitive advantage: a resource-based perspective. In: International Journal of Human Resource Management, 5(2): 301-326.

Wright, P. M./Sherman, W. S. (1999): Failing to find fit in strategic human resource management: theoretical and empirical problems. In: Research in Personnel and Human Resources Management, supplement 4: 53-74.

Youndt, M. A./Snell, S. A./Dean Jr., J. W./Lepak, D. P. (1996): Human resource management, manufacturing strategy and firm performance. In: Academy of Management Journal, 39(4): 836-866.

Youndt, M. A./Snell, S. A./Dean Jr., J. W./Lepak, D. P. (1996): Human resource management, manufacturing strategy and firm performance. In: Academy of Management Journal, 39(4): 836-866.

Zedeck, S./Cascio, W. (1984): Psychological Issues in Personnel Decisions. In: Annual Review of Psychology, 35: 461-519. 